Article

\title{
Energy, Exergy, Exergoeconomic, and Exergoenvironmental Assessment of Flash-Binary Geothermal Combined Cooling, Heating and Power Cycle
}

\author{
Moein Shamoushaki ${ }^{1}$ (D), Mehdi Aliehyaei ${ }^{2, *}$ and Farhad Taghizadeh-Hesary ${ }^{3, *(D)}$ \\ 1 Department of Industrial Engineering, University of Florence, 50134 Florence, Italy; \\ moein.shamoushaki@unifi.it \\ 2 Department of Mechanical Engineering, Pardis Branch, Islamic Azad University, \\ Pardis New City 1468995513, Iran \\ 3 Social Science Research Institute, Tokai University, 4-1-1 Kitakaname, Hiratsuka-shi 259-1292, Japan \\ * Correspondence: aliehyaei@pardisiau.ac.ir (M.A.); farhad@tsc.u-tokai.ac.jp (F.T.-H.)
}

check for

updates

Citation: Shamoushaki, M.;

Aliehyaei, M.; Taghizadeh-Hesary, F.

Energy, Exergy, Exergoeconomic, and

Exergoenvironmental Assessment of

Flash-Binary Geothermal Combined

Cooling, Heating and Power Cycle.

Energies 2021, 14, 4464. https://

doi.org/10.3390/en14154464

Academic Editor:

Paul Christodoulides

Received: 5 July 2021

Accepted: 21 July 2021

Published: 23 July 2021

Publisher's Note: MDPI stays neutral with regard to jurisdictional claims in published maps and institutional affiliations.

Copyright: (c) 2021 by the authors. Licensee MDPI, Basel, Switzerland. This article is an open access article distributed under the terms and conditions of the Creative Commons Attribution (CC BY) license (https:/ / creativecommons.org/licenses/by/ $4.0 /)$.

\begin{abstract}
This research presents the energy, exergy, economic, and environmental assessment, and multi-objective optimization of a flash-binary geothermal CCHP cycle. A sensitivity analysis of production well inlet temperature and cooling to power flow ratio on exergetic, economic, and environmental parameters was conducted. Furthermore, the effects of the inflation rate and plant working hours on economic parameters were investigated. Results showed that increasing the production well inlet temperature harms exergy efficiency and exergetic performance criteria and results in a gain in exergo-environmental impact index and heating capacity. In addition, the total plant cost increased by raising the production well temperature. Furthermore, increasing the cooling to power flow ratio caused a reduction in exergy efficiency, exergetic performance criteria, and produced net power and an enhancement in exergy destruction, cooling capacity, and total plant cost. The exergy efficiency and total cost rate in the base case were $58 \%$ and 0.1764 , respectively. Optimization results showed that at the selected optimum point, exergy efficiency was $4.5 \%$ higher, and the total cost rate was $10.3 \%$ lower than the base case. Levelized cost of energy and the pay-back period at the optimum point was obtained as $6.22 \mathrm{c} \$ / \mathrm{kWh}, 3.43$ years, which were $5.14 \%$ and $6.7 \%$ lower than the base case.
\end{abstract}

Keywords: exergy; exergoeconomic; CCHP; geothermal; ORC

\section{Introduction}

Energy and electricity demand in recent years is increasing, so researchers and industries are focusing on systems with higher productivity. Combined cooling heating and power $(C C H P)$ is one of the most exciting solutions for researchers. Additionally, using renewable energies as a heat source has gained the attention of researchers. Geothermal energy is one of the most favorable renewable energies including unique features such as dependability and sustainability with a temperature range varying from 50 to $350{ }^{\circ} \mathrm{C}[1,2]$.

Ebrahimi et al. [3] analyzed a CCHP system according to energy and exergy concepts. They conducted some parametric evaluations such as inlet pressure and temperature of the turbine effects on system productivity. Their results showed that the most considerable exergy destruction in summer and winter is related to the vapor generator. Tempesti and Ahmadi et al. [4] analyzed a multi-generation $O R C$ to generate power, cooling, and hydrogen from energy, exergy, and environmental aspects. They undertook multi-objective optimization to find the most favorable design parameters and minimized the system's total cost rate and maximized the efficiency of exergy. Al-Ali and Dincer [5] carried out an energy and exergy analysis of a multigenerational integrated geothermal and solar system to produce electricity, cooling, heating, and hot water. Their results presented 
the efficiency of the multi-generation exergy as $36.6 \%$ and the single generation as $26.2 \%$. Ehyaei et al. [6] carried out an exergy, economic, and environmental assessment of a $\mathrm{CHP}$ internal combustion engine. Their results showed that an enormous amount of molar air to fuel ratio led to fewer electricity values and external costs. Additionally, the environmental impact depends on the system location and engine operation time. Chaiyat and Kiatsiriroat [7] investigated the feasibility of increasing ORC efficiency by the CCHP system from an absorption system according to the energy, economic, and environmental aspects. Their results illustrated that the ORC cycle with the absorption system had more efficiency than the ORC.

Darvish et al. [8] investigated the best working fluid for a regenerative ORC with low-temperature resources. Their results showed that the most considerable portion of exergy destruction is relevant to the boiler and expander. Imran et al. [9] studied three different geothermal ORC cycles (basic, recuperated, and regenerative ORC) from the energy and exergy points of view. They compared these cycles at optimum operating conditions by minimizing the specific investment cost and maximizing the efficiency. Zhao and Wang [10] performed an exergoeconomic assessment of a flash-binary geothermal cycle using ORC. A parametric study of flash pressure, ORC turbine inlet pressure, and temperature was conducted. Haghighi et al. [11] performed a comprehensive study of previous research done on ORC cycles with different operating conditions and configurations. They found that according to the geothermal-based ORC cycle features, the final efficiency and cost differed extensively. Anvari et al. [12] carried out a thermo-economic evaluation of a combined system. Additionally, they considered the effect of adding a regenerative $O R C$ to the gas turbine and heat recovery steam generator. Aali et al. [13] conducted exergoeconomic analysis and single optimization of a single flash geothermal cycle. They assessed the effect of wellhead temperature and pressure differences of existing wells in the Sabalan area in Iran. Ahmadi Boyaghchi and Chavoshi [14] carried out energy, exergy, exergoeconomic, and environmental assessment of a solar-geothermal driven CCHP. They optimized this system for four different working fluids by the Non-dominated Sorting Genetic Algorithm II (NSGA-II) to reach optimum solutions. They compared the effect of these fluids on system performance. Shamoushaki et al. [15] carried out energy, exergy, exergoeconomic, and environmental assessments of a solid oxide fuel cell and gas turbine (SOFC-GT) system. They undertook multi-objective optimization of the considered system by the NSGA-II algorithm and performed a sensitivity evaluation of fuel cost per unit of energy effect on the efficiency of exergy and overall cost rate.

Ghaebi et al. [16] proposed a Kalina system and an ejector refrigeration combined cycle to generate power and cooling. They analyzed the main parameter changes on net-work, exergy, and thermal efficiencies, and capacity of refrigeration. Bianchi et al. [17] studied a micro-ORC case study using geothermal energy. Their results showed that the expander and feed pump efficiencies and the ORC efficiency at the geothermal well's arranged working conditions were $53 \%, 41 \%$, and $4.4 \%$, respectively. Leveni et al. [18] carried out an energy and exergy analysis of ORC integrated with a $\mathrm{LiBr} /$ water absorption chiller with the geothermal resource of Torre Alfina in the center of Italy. They developed the thermodynamic model in Engineering Equation Solver (EES) software and conducted a sensitivity analysis to study the plant operating range and the feasibility of design in adjusting to the customers' needs. Khosravi et al. [2] proposed an artificial intelligence approach to model geothermal ORC power systems. Their presented model predicted the net generated power, energy, and exergy efficiencies, and levelized cost of energy (LCOE) of the geothermal ORC system. Ehyaei et al. [19] conducted an exergy and exergoeconomic investigation of a combined geothermal cooling and power system. Their considered system was an ORC as an upper and the absorption chiller as the bottom cycles. They also carried out an optimization of this system by the particle swarm optimization (PSO) algorithm. Braimakis et al. [20] conducted an energy and exergy assessment of the ultra-supercritical biomass-fueled steam cycle. They performed sensitivity analyses for 
widespread ranges of heat demand. Their results illustrated that most exergy destructions were due to combustion and steam generation.

Wang et al. [21] conducted a thermodynamic and exergy analysis of a power and cooling generation system based on geothermal flash, organic Rankine, and ejector refrigeration cycles. They applied different working fluids to obtain a better system performance. Their results showed that a system with isopentane $(0.3) / \mathrm{R} 142 \mathrm{~b}(0.7)$ as a working fluid had the highest exergy efficiency and lowest exergy destruction. Tian et al. [22] studied a cogeneration double flash-binary geothermal power cycle to produce cooling and power. They performed multi-objective optimization of the system that caused a $20.59 \%$ increase in the net electrical power and $68.11 \%$ growth in exergy efficiency. Ahmadi et al. [23] investigated different $O R C$ applications for power production from geothermal resources. They compared the considered configurations from the ORC economic index to find the most affordable cycle. Assad et al. [24] carried out an energy and exergy assessment of a single flash geothermal power cycle at the optimum separator temperature. Results showed that maximum energy efficiency at the well temperatures of 300, 275, and $250 \mathrm{~K}$ was $12.5,11$, and $9.5 \%$, respectively. Gholizadeh et al. [25] found that flash-binary geothermal cycles are a promising technology to extend trigeneration systems for the generation of heating, cooling, and freshwater; however, they have received less attention. Ding et al. [26] proposed a combined flash-binary to generate cooling and power using a zeotropic fluid. They optimized the system using the NSGA-II algorithm to find the best operational parameters. Cao et al. [27] evaluated a double-flash-binary geothermal system to generate power and cooling. A sensitivity assessment of separator and condenser pressures and evaporator temperature variations on the system performance is done.

In the present research, the energy, exergy, economic, and environmental analysis of a flash-binary geothermal CCHP cycle is done. This combined system aims to generate power and heating by flash cycle and produce power and cooling by the ORC section. Thermodynamic modeling was expanded in MATLAB using Refprop 9.1 [28], and the thermodynamic properties of all points were obtained. The discretization method was applied to calculate a more accurate heat exchanger area value, which directly and significantly impacts the equipment cost. The optimization was carried out by the NSGA-II algorithm to reach an optimum solution and find the best design variable values. Two considered objective functions were total cost rate and exergy efficiency. Most researchers considered the various working fluids' impact on the system performance. Others have evaluated CCHP systems with various configurations and different heat sources (gas turbine, solargeothermal, fuel cell, etc.). Reviewing previous studies showed that many researchers have analyzed flash-binary systems from different aspects. They mainly focused on assessing the inlet temperature and pressure of the turbine and separator pressure impacts on system performance. However, in this study, the authors concentrated on the effects of the parameters that have not been considered widely in previous research such as cooling to power ratio, interest rate, plant working hours, and saved values of carbon dioxide and fuel. In addition, the designed configuration in this study has not been evaluated in other studies. The novelty and work done in this research are:

- Sensitivity analysis of production well temperature and cooling to power flow ratio variations impact on the exergetic, economic, and environmental parameters;

- Sensitivity analysis of the interest rate and plant working hours effects on the economic parameters;

- Evaluating the change in these parameters on the exergo-environmental impact index to find the most environmentally friendly system;

- The pay-back period estimation; and

- Calculation of the saved amount of $\mathrm{CO}_{2}$ and fuel consumption of the cycle due to using geothermal energy as a heat resource. 


\section{Materials and Methods}

\subsection{System Description}

The schematic diagram of the flash-binary geothermal CCHP cycle is illustrated in Figure 1. The applied working fluid in the ORC cycle was isobutene. The temperature, pressure, and mass flow rate of the geofluid was $443.2 \mathrm{~K}, 901.3 \mathrm{kPa}$, and $100 \mathrm{~kg} / \mathrm{s}$, respectively. In this system, the hot water of residential buildings was produced by geothermal fluid (pure water), and cooling water was produced by the ORC cycle.

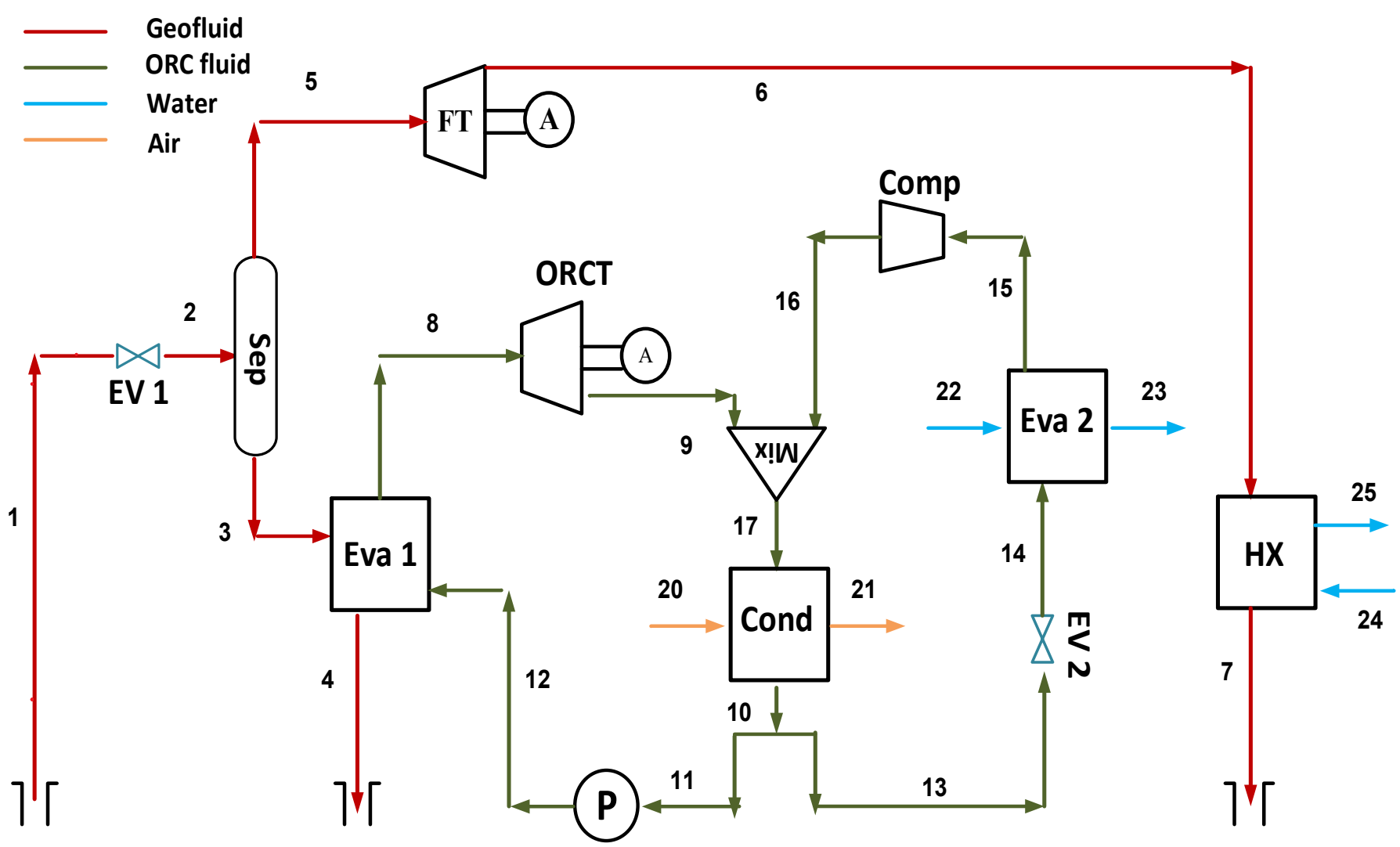

Figure 1. Schematic diagram of the evaluated flash-binary geothermal combined cooling heating and power.

In this system, geothermal fluid (water) with the heat obtained from geothermal resources (point 1) passes through the expansion valve. After pressure reduction, it goes into two phases. In the separator, these two-phase separate into two lines. The separator is adiabatic and reversible, so it operates at the same temperature. After entering into a flash turbine, the vapor generates power and flows into the heat exchanger to produce hot water for residential consumption and then goes to the injection well. Saturated liquid flows into evaporator 1 and gets its heat to the ORC fluid (isobutane), and water goes to the injection well. The ORC fluid with high enthalpy flows into the ORC turbine and generates power, then flows into the mixer, and after mixing with fluid coming from the compressor, it goes into the condenser to cool down by entering the air. Afterward, ORC fluid is divided into two flows to regulate the cooling to power ratio $(\alpha)$, which in this study was considered as 0.2 . Fluid through line 11 goes to the pump (to recirculate the ORC part for power generation) and through 14 flows into the expansion valve. After reducing the pressure by an expansion valve, it enters into an evaporator and absorbs heat from the water to produce cooled water for the cooling system, then flows into the compressor. The temperature-entropy (T-s) diagram is shown in Figure 2. In this figure, points 1, 4, and 7 are related to geothermal water. 


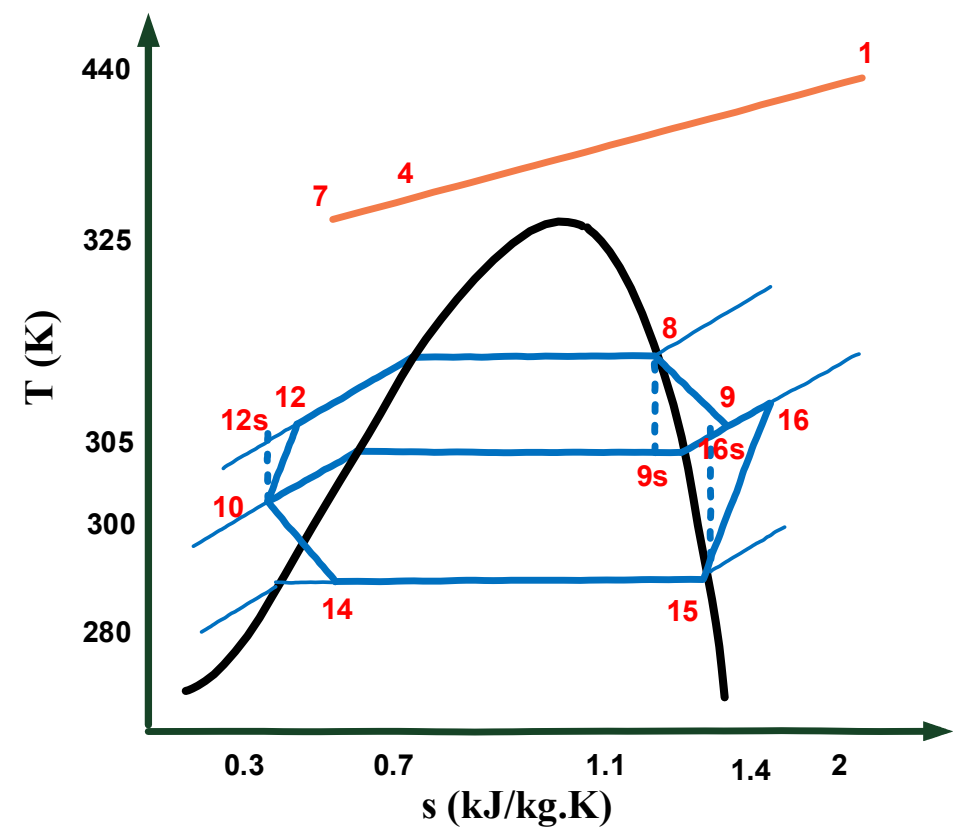

Figure 2. T-s diagram for the ORC working fluid.

\subsection{Energy and Exergy Modeling}

Mathematical modeling is done according to the first and second laws of thermodynamics. Some assumptions considered in this research are as follows:

- The system operates under steady-state conditions [15].

- The potential and kinetic energy are considered insignificant [19].

- The ambient temperature and pressure are supposed $298.15 \mathrm{~K}$ and $1.013 \mathrm{kPa}$ [8].

- The pump, turbines, and compressors have isentropic efficiencies, that their values are brought in Table 1 [19].

- The pressure losses of pipelines and all components are supposed to be negligible [29]. The mass and energy balance equations are written as follows [30]:

$$
\begin{aligned}
\sum \dot{m}_{i} & =\sum \dot{m}_{e} \\
\sum(\dot{m} h)_{i}+\dot{Q} & =\sum(\dot{m} h)_{e}+\dot{W}
\end{aligned}
$$

Table 1. Input parameters in thermodynamic modeling.

\begin{tabular}{cccc}
\hline Parameter & Unit & Value & Ref \\
\hline$P_{1}$ & $\mathrm{kPa}$ & 901.3 & {$[31]$} \\
$\mathrm{T}_{1}$ & $\mathrm{~K}$ & 443.2 & {$[31]$} \\
$\dot{m}_{1}$ & $\mathrm{~kg} / \mathrm{s}$ & 100 & - \\
$\mathrm{T}_{4}$ & $\mathrm{~K}$ & 333.2 & - \\
$\mathrm{T}_{7}$ & $\mathrm{~K}$ & 328.2 & - \\
$\mathrm{T}_{23}$ & $\mathrm{~K}$ & 281.2 & - \\
$\mathrm{T}_{25}$ & $\mathrm{~K}$ & 323.2 & - \\
$\eta_{p}$ & $\%$ & 85 & {$[19]$} \\
$\eta_{F T}$ & $\%$ & 85 & {$[19]$} \\
$\eta_{\text {ORCT }}$ & $\%$ & 85 & {$[19]$} \\
$\eta_{\text {Comp }}$ & $\%$ & 75 & {$[32]$} \\
$x_{3}$ & - & 0 & - \\
$x_{5}$ & - & 1 & - \\
$P_{0}$ & $\mathrm{kPa}$ & 101.3 & {$[8]$} \\
$\mathrm{T}_{0}$ & $\mathrm{~K}$ & 298.15 & {$[8]$} \\
\hline
\end{tabular}


Here, $i$ and $e$ are related to the control volume inlet and outlet. $\dot{m}, h, \dot{Q}$, and $\dot{W}$ are mass flow rate $(\mathrm{kg} / \mathrm{s})$, specific enthalpy $(\mathrm{kJ} / \mathrm{kg})$, heat transfer, and work, respectively $(\mathrm{kW})$. Input parameters for the thermodynamic evaluation of this cycle are presented in Table 1. The pressure and temperature of the geothermal fluid were selected according to Wang et al. [31]. Additionally, the mass and energy balance correlations are presented in Table 2. The thermal efficiency can be calculated as [23]:

$$
\eta_{t h}=\frac{\dot{W}_{n e t}}{\dot{Q}_{i n}}
$$

Table 2. Equations of mass and energy balances [33].

\begin{tabular}{|c|c|c|c|}
\hline No & Component & Mass Balance & Energy Balance \\
\hline 1 & $E V 1$ & $\dot{m}_{1}=\dot{m}_{2}$ & - \\
\hline 2 & Sep & $\dot{m}_{2}=\dot{m}_{3}+\dot{m}_{5}$ & - \\
\hline 3 & Eva 1 & $\begin{array}{l}\dot{m}_{3}=\dot{m}_{4} \\
\dot{m}_{12}=\dot{m}_{8}\end{array}$ & $\dot{Q}_{E v a 1}=\dot{m}_{3}\left(h_{3}-h_{4}\right)=\dot{m}_{12}\left(h_{8}-h_{12}\right)$ \\
\hline 4 & $F T$ & $\dot{m}_{5}=\dot{m}_{6}$ & $\dot{W}_{F T}=\dot{m}_{5}\left(h_{5}-h_{6}\right) \eta_{F T}$ \\
\hline 5 & $H X$ & $\begin{aligned} \dot{m}_{6} & =\dot{m}_{7} \\
\dot{m}_{24} & =\dot{m}_{25}\end{aligned}$ & $\dot{Q}_{H X}=\dot{m}_{6}\left(h_{6}-h_{7}\right)=\dot{m}_{24}\left(h_{25}-h_{24}\right)$ \\
\hline 6 & ORCT & $\dot{m}_{8}=\dot{m}_{9}$ & $\dot{W}_{F T}=\dot{m}_{8}\left(h_{8}-h_{9}\right) \eta_{O R C T}$ \\
\hline 7 & Cond & $\begin{array}{l}\dot{m}_{10}=\dot{m}_{17} \\
\dot{m}_{20}=\dot{m}_{21}\end{array}$ & $\dot{Q}_{\text {Cond }}=\dot{m}_{10}\left(h_{17}-h_{10}\right)=\dot{m}_{20}\left(h_{21}-h_{20}\right)$ \\
\hline 8 & Pump & $\dot{m}_{11}=\dot{m}_{12}$ & $\dot{W}_{p}=\left(\dot{m}_{11}\left(h_{11}-h_{12}\right) / \eta_{p}\right)$ \\
\hline 9 & $E V 2$ & $\dot{m}_{13}=\dot{m}_{14}$ & - \\
\hline 10 & Eva 2 & $\begin{array}{l}\dot{m}_{22}=\dot{m}_{23} \\
\dot{m}_{14}=\dot{m}_{15}\end{array}$ & $\dot{Q}_{E v a 1}=\dot{m}_{14}\left(h_{15}-h_{14}\right)=\dot{m}_{22}\left(h_{22}-h_{23}\right)$ \\
\hline 11 & Comp & $\dot{m}_{15}=\dot{m}_{16}$ & $\dot{W}_{\text {Comp }}=\left(\dot{m}_{15}\left(h_{15}-h_{16}\right) / \eta_{\text {Comp }}\right)$ \\
\hline 12 & Mixer & $\dot{m}_{17}=\dot{m}_{9}+\dot{m}_{16}$ & $\dot{m}_{17} h_{17}=\dot{m}_{9} h_{9}+\dot{m}_{16} h_{16}$ \\
\hline
\end{tabular}

Exergy is the highest theoretical work that can be achieved from an energy system. The exergy balance of each piece of equipment is [34,35]:

$$
\begin{aligned}
\sum(\dot{m} . e x)_{i}+\dot{E} x_{Q} & =\sum(\dot{m} \cdot e x)_{e}+\dot{E} x_{W}+\dot{E} x_{D} \\
\dot{E} x_{Q} & =\left(1-\frac{\mathrm{T}_{0}}{\mathrm{~T}}\right) \dot{Q}_{k}
\end{aligned}
$$

where $e x$ is the specific exergy of each stream $(\mathrm{kJ} / \mathrm{kg})$, and $\dot{E} x_{Q}, \dot{E} x_{W}$, and $\dot{E} x_{D}$ are the exergy of heat transfer, work, and exergy destruction of each component $(\mathrm{kW})$, respectively. Exergy is divided into four different sections: kinetic, potential, physical, and chemical, and in this study, the chemical, kinetic, and potential were considered insignificant. The physical exergy of each stream is $[34,36]$ :

$$
e x_{p h, k}=\left(h-h_{0}\right)_{k}-\mathrm{T}_{0}\left(s-s_{0}\right)_{k}
$$

In the above equation, 0 refers to the reference condition, which is the same as the ambient condition. $s$ is the specific entropy $(\mathrm{kJ} / \mathrm{kg} . \mathrm{K})$ and subscript $k$ refers to the kth component. The exergy destruction equations for the whole equipment are presented in Table 3. Exergy analysis of a system, one of the most significant variables, is the exergy destruction ratio, which defines the exergy destruction of each piece of equipment divided into total exergy destruction [12].

$$
y_{D, k}=\frac{\dot{E} x_{D_{k}}}{\dot{E} x_{D_{T o t}}}
$$


Table 3. The exergy destruction rate equation of all components.

\begin{tabular}{ccc}
\hline No & Component & Exergy Destruction \\
\hline 1 & $E V 1$ & $\dot{E} x_{D, E V 1}=\dot{E} x_{1}-\dot{E} x_{2}$ \\
2 & Sep & $\dot{E} x_{D, S e p}=\dot{E} x_{2}-\dot{E} x_{3}-\dot{E} x_{5}$ \\
3 & $E v a 1$ & $\dot{E} x_{D, E v a 1}=\dot{E} x_{3}+\dot{E} x_{12}-\dot{E} x_{4}-\dot{E} x_{8}$ \\
4 & $F T$ & $\dot{E} x_{D, F T}=\dot{E} x_{5}-\dot{E} x_{6}-\dot{W_{F T}}$ \\
5 & $H X$ & $\dot{E} x_{D, H X}=\dot{E} x_{6}+\dot{E} x_{24}-\dot{E} x_{7}-\dot{E} x_{25}$ \\
6 & ORCT & $\dot{E} x_{D, F T}=\dot{E} x_{8}-\dot{E} x_{9}-\dot{W_{O R C T}}$ \\
7 & Cond & $\dot{E} x_{D, C o n d}=\dot{E} x_{17}+\dot{E} x_{20}-\dot{E} x_{10}-\dot{E} x_{21}$ \\
8 & Pump & $\dot{E} x_{D, p}=\dot{E} x_{1}-\dot{E} x_{2}+\dot{W_{p}}$ \\
9 & $E V 2$ & $\dot{E} x_{D, E V 2}=\dot{E} x_{13}-\dot{E} x_{14}$ \\
10 & Eva 2 & $\dot{E} x_{D, E v a 1}=\dot{E} x_{14}+\dot{E} x_{22}-\dot{E} x_{15}-\dot{E} x_{23}$ \\
11 & Comp & $\dot{E} x_{D, C o m p}=\dot{E} x_{15}-\dot{E} x_{16}+\dot{W}{ }_{C o m p}$ \\
12 & Mixer & $\dot{E} x_{D, M i x e r}=\dot{E} x_{9}+\dot{E} x_{16}-\dot{E} x_{17}$ \\
\hline
\end{tabular}

Additionally, the exergetic efficiency of each piece of equipment can be obtained as:

$$
\eta_{e x, k}=\frac{\dot{E} x_{P, k}}{\dot{E} x_{F, k}}
$$

Here, $\dot{E} x_{P, k}$ and $\dot{E} x_{F, k}$ are the exergy flow rate of product and fuel, respectively. Moreover, the coefficient of performance (COP) of the refrigeration part can be obtained as follows [19]:

$$
C O P=\frac{\dot{Q}_{E v a}}{\dot{W}_{\text {Comp }}}
$$

Exergetic performance criteria $(E P C)$ is useful for technical decisions and can be written as [37]:

$$
E P C=\frac{\dot{W}_{n e t}}{\dot{E} x_{D, T o t}}
$$

The efficiency of exergy of the whole cycle is [38]:

$$
\eta_{e x}=\frac{\dot{W}_{n e t}}{\dot{E} x_{i n}}
$$

\subsection{Exergo-Economic Modeling}

Exergoeconomic is a powerful and influential knowledge driven by a combination of economic and exergy concepts. It helps researchers reach a better understanding of systems from energy and economic points of view. It makes possible the economic design of energy systems that are not obtainable by standard economic modeling [34]. In the present study, the specific exergy costing (SPECO) method was applied to this system's exergoeconomic evaluation [39]. To the exergoeconomic modeling of this system, cost balance and auxiliary equations are considered, as presented in Table 4. Equation of cost balance for whole equipment is as follows [34,40]:

$$
\dot{C}_{q, k}+\sum \dot{C}_{i, k}+\dot{Z}_{k}=\dot{C}_{w, k}+\sum \dot{C}_{e, k}
$$


where $\dot{C}_{q, k}$ is the unit cost rate of heat transfer $(\$ / s) ; \dot{C}_{w, k}$ is the unit cost rate of work (\$/s), and $\dot{Z}_{k}$ is the capital cost rate. $\dot{C}_{i, k}$ and $\dot{C}_{e, k}$ are the inlet and outlet cost unit (\$/s), respectively. Unit cost rate can be written as $[34,40]$ :

$$
\dot{C}_{k}=c_{k} \dot{E} x_{k}
$$

where $c_{k}$ and $\dot{E} x_{k}$ are cost per unit of energy $(\$ / \mathrm{kJ})$ and exergy rate of the kth stream of the cycle $(\mathrm{kW})$, respectively. The total cost rate of the cycle is the sum of capital investments $(C I)$ and operating and maintenance $(\mathrm{O} \& \mathrm{M})$ cost, then $[34,41]$ :

$$
\dot{Z}_{k}=\dot{Z}_{k}^{C I}+\dot{Z}_{k}^{O M}=\frac{Z_{k} \times C R F \times \varphi}{N \times 3600}
$$

Table 4. Cost balance and auxiliary equations.

\begin{tabular}{ccc}
\hline Component & Cost Balance Equation & Auxiliary Equation \\
\hline$E V 1$ & $\dot{C}_{1}+\dot{Z}_{E V 1}=\dot{C}_{2}$ & - \\
Sep & $\dot{C}_{2}+\dot{Z}_{S e p}=\dot{C}_{3}+\dot{C}_{5}$ & $c_{3}=c_{5}$ \\
Eva 1 & $\dot{C}_{3}+\dot{C}_{12}+\dot{Z}_{E v a 1}=\dot{C}_{4}+\dot{C}_{8}$ & $c_{3}=c_{4}$ \\
$F T$ & $\dot{C}_{5}+\dot{Z}_{F T}=\dot{C}_{26}+\dot{C}_{W, F T}$ & $c_{5}=c_{6}$ \\
$H X$ & $\dot{C}_{6}+\dot{C}_{24}+\dot{Z}_{H X}=\dot{C}_{7}+\dot{C}_{25}$ & $c_{6}=c_{7,}, c_{24}=0$ \\
ORCT & $\dot{C}_{8}+\dot{Z}_{O R C T}=\dot{C}_{9}+\dot{C}_{W, O R C T}$ & $c_{8}=c_{9}, c_{W, O R C T}=c_{W, F T}$ \\
Cond & $\dot{C}_{17}+\dot{C}_{20}+\dot{Z}_{C o n d}=\dot{C}_{10}+\dot{C}_{21}$ & $c_{20}=0, c_{17}=c_{10}, c_{11}=c_{10}$ \\
Pump & $\dot{C}_{11}+\dot{C}_{W, p}+\dot{Z}_{p}=\dot{C}_{12}$ & $c_{W, p}=c_{W, O R C T}$ \\
EV 2 & $\dot{C}_{14}+\dot{C}_{22}+\dot{Z}_{E v a 2}=\dot{C}_{15}+\dot{C}_{23}$ & $c_{14}=c_{15,}, c_{22}=0$ \\
Eva 2 & $\dot{C}_{13}+\dot{Z}_{E V 2}=\dot{C}_{14}$ & - \\
Comp & $\dot{C}_{15}+\dot{C}_{W, C o m p}+\dot{Z}_{C o m p}=\dot{C}_{16}$ & $c_{W, C o m p}=c_{W, p}$ \\
Mixer & $\dot{C}_{9}+\dot{C}_{16}+\dot{Z}_{M i x}=\dot{C}_{17}$ & $c_{11}=c_{13}$ \\
\hline
\end{tabular}

In this equation, $Z_{k}, \varphi$, and $N$ are the investment cost of the $k$ th component (\$), maintenance factor, and annual plant working hours (considered as $7446 \mathrm{~h} \mathrm{[14]),} \mathrm{respectively.}$ The purchasing cost correlations and their constant values are presented in Tables 5 and 6 , respectively. Capital recovery factor $(C R F)$ can be expressed as [34,42]:

$$
C R F=\frac{i(1+i)^{n}}{(1+i)^{n}-1}
$$

Here, $i$ is the rate of interest which is considered 10\% [43], and $n$ is the useful life of the cycle that is supposed to be 30 years in the current study. In the exergoeconomic evaluation, by introducing each component product and fuel, the product and fuel cost of components can be calculated. Moreover, the cost rate related to exergy destruction can be obtained by multiplying specific fuel costs and exergy destruction of each equipment [34].

$$
\begin{aligned}
\dot{C}_{P, k} & =c_{P, k} \dot{E} x_{P, k} \\
\dot{C}_{F, k} & =c_{F, k} \dot{E} x_{F, k} \\
\dot{C}_{D, k} & =c_{F, k} \dot{E} x_{D, k}
\end{aligned}
$$

where in these equations, $c_{P, k}$ and $c_{F, k}$ are the specific cost of product and fuel $(\$ / \mathrm{kJ})$, respectively. $\dot{C}_{D, k}$ is the exergy destruction cost rate of the kth component $(\$ / \mathrm{s})$. The 
purchased equipment costs are shown in Table 5. Furthermore, the exergoeconomic factor and relative cost difference can be calculated as follows [34,44]:

$$
\begin{aligned}
f_{k} & =\frac{\dot{Z}_{k}}{\dot{Z}_{k}+\dot{C}_{D, k}} \\
r_{k} & =\frac{c_{P, k}-c_{F, k}}{c_{F, k}}
\end{aligned}
$$

Table 5. The purchased equipment cost of all components.

\begin{tabular}{ccc}
\hline Component & Cost Correlation & Ref \\
\hline Pump & $Z_{p}=1120 \times\left(\dot{W}_{p}\right)^{0.8}$ & {$[45]$} \\
Compressor & $\log C_{0}=\left[\begin{array}{c}\left.K_{1, \operatorname{Comp}}+K_{2, \text { Comp }}(\log \dot{W})+K_{3, \operatorname{Comp}}(\log \dot{W})^{2}\right] \\
Z_{\text {Comp }}=C_{0} \times F_{B M, \text { Comp }}\end{array}\right.$ \\
Turbines & $\log C_{0, t}=\left[\begin{array}{c}\left.K_{1, t}+K_{2, t}\left(\log \dot{W}_{t 1}\right)+K_{3, t}\left(\log \dot{W}_{t 1}\right)^{2}\right] \\
Z_{t 1}=C_{0, t} \times F_{M, t}\end{array}\right.$ \\
Heat exchangers & $\log C_{0, H X}=\left[K_{1, H X}+K_{2, H X}\left(\log A_{H X}\right)+K_{3, H X}\left(\log A_{H X}\right)^{2}\right]$ \\
Expansion valves & $\log F_{P, H X}=\left[C_{1, H X}+C_{2, H X}\left(\log P_{H X}\right)+C_{3, H X}\left(\log P_{H X}\right)^{2}\right]$ & \\
Separator & $Z_{H X}=C_{0, H X} \times\left[B_{1, H X}+\left(B_{2, H X} \times F_{M, H X} \times F_{P, H X}\right)\right]$ \\
Mixer & $Z_{E V}=114.5 \times \dot{m}$ & {$[46]$} \\
$Z_{S e p}=280.3 \times(\dot{m})^{0.67}$ & 0 \\
\hline
\end{tabular}

Table 6. Constant values of cost correlation in Table 5 [46].

\begin{tabular}{cccccccc}
\hline Parameter & Value & Parameter & Value & Parameter & Value & Parameter & Value \\
\hline$K_{1, t}$ & 2.6259 & $K_{3, \text { Comp }}$ & -0.1027 & $C_{2, H X}$ & -0.00627 & $B_{1, H X}$ & 1.63 \\
$K_{2, t}$ & 1.4398 & $K_{1, H X}$ & 4.1884 & $C_{3, H X}$ & 0.0123 & $B_{2, H X}$ & 1.66 \\
$K_{3, t}$ & -0.1776 & $K_{2, H X}$ & -0.2503 & $C_{1, \text { Cond }}$ & 0 & $B_{1, \text { Cond }}$ & 0.96 \\
$K_{1, \text { Cond }}$ & 4.0336 & $K_{3, H X}$ & 0.1974 & $C_{2, \text { Cond }}$ & 0 & $B_{2, \text { Cond }}$ & 1.21 \\
$K_{2, \text { Cond }}$ & 0.2341 & $K_{1, E v a}$ & 4.642 & $C_{3, \text { Cond }}$ & 0 & $F_{B M, t}$ & 6.1 \\
$K_{3, \text { Cond }}$ & 0.0497 & $K_{2, E v a}$ & 0.3698 & $C_{1, E v a}$ & 0.1578 & $F_{B M, \text { Comp }}$ & 2.8 \\
$K_{1, \text { Comp }}$ & 2.2897 & $K_{3, E v a}$ & 0.0025 & $C_{2, \text { Eva }}$ & -0.2992 & $F_{M, E v a}$ & 2 \\
$K_{2, \text { Comp }}$ & 1.3604 & $C_{1, H X}$ & -0.00164 & $C_{3, \text { Eva }}$ & 0.1413 & $F_{M, \text { Cond }}$ & 1 \\
\hline
\end{tabular}

The CEPCI (Chemical Engineering Plant Cost Index) is applied to compensate for the inflation rate. This index is updated to the year $2018[50,51]$.

$$
P E C_{k}=Z_{k} \times\left(\frac{C E P C I_{2018}}{C E P C I_{2001}}\right)
$$

\subsection{Heat Exchangers Area Calculation}

The discretization method is applied to calculate the heat transfer coefficient $(U)$ and area $(A)$ by partitioning the heat exchanger area into minor parts. It is essential because the area of heat exchangers has direct impacts on their purchase cost. The below equation can be used for each section:

$$
\dot{Q}_{j}=U_{j} A_{j} \Delta \mathrm{T}_{L M T D j}
$$

where

$$
\Delta \mathrm{T}_{\text {LMTD }}=\frac{\left(\mathrm{T}_{\text {hot }, \text { out }}-\mathrm{T}_{\text {cold, in }}\right)-\left(\mathrm{T}_{\text {hot, in }}-\mathrm{T}_{\text {cold,out }}\right)}{\ln \left(\left(\mathrm{T}_{\text {hot }, \text { out }}-\mathrm{T}_{\text {cold }, \text { in }}\right) /\left(\mathrm{T}_{\text {hot }, \text { in }}-\mathrm{T}_{\text {cold }, \text { out }}\right)\right)}
$$

To calculate the convective heat transfer coefficient, it can be written as:

$$
\alpha=\frac{N u \lambda}{d}
$$


In this equation, $N u$ is the Nusselt number and $\lambda$ is the thermal conductivity $(\mathrm{W} / \mathrm{mK})$. The Nusselt number can be calculated by the Dittus Boelter correlation as follows [52]:

$$
N u=0.023 \times \operatorname{Pr}^{n} \times R e^{0.8}
$$

In the above equation, $\mathrm{Pr}$ is the Prandtl number, and $R e$ is the Reynolds number. Furthermore, $n$ for the cooling and heating process are 0.3 and 0.4, respectively [52]. For the calculation of the condenser area, the below equation is used to obtain the Nusselt number [53]:

$$
\left\{\begin{array}{cc}
N u=1.47 R e^{-1 / 3} & R e \leq 30 \\
N u=\frac{R e}{1.08 R e^{2.22}-5.2} & 30 \leq R e \leq 1800 \\
N u=\frac{R e}{8750+58 P^{-0.5}\left(R e^{0.75}-253\right)} & R e \geq 1800, \operatorname{Pr} \geq 1
\end{array}\right.
$$

Additionally, to calculate the evaporator area, the below correlation is applied [54]:

$$
\begin{gathered}
N u(j)_{b}=0.0183 \operatorname{Re}(j)_{b}^{0.82} \operatorname{Pr}(j)^{0.5}\left(\frac{\rho_{w a}(j)}{\rho_{b}(j)}\right)^{0.3}\left(\frac{\bar{c}_{p}(j)}{c_{p b}(j)}\right)^{n} \\
n=\left\{\begin{array}{cl}
0.4, \quad \text { if } \mathrm{T}_{b}<\mathrm{T}_{w a}<\mathrm{T}_{p c} & \text { and } \mathrm{T}_{p c}<\mathrm{T}_{b}<\mathrm{T}_{w a} \\
0.4+0.2\left(\frac{\mathrm{T}_{w w a}}{\mathrm{~T}_{p c}}-1\right), & \text { if } \mathrm{T}_{b}<\mathrm{T}_{p c}<\mathrm{T}_{w a} \\
0.4+0.2\left(\frac{\mathrm{T}_{w w a}}{\mathrm{~T}_{p c}}-1\right)\left[1-5\left(\frac{\mathrm{T}_{b}}{\mathrm{~T}_{p c}}-1\right)\right], & \text { if } \mathrm{T}_{p c}<\mathrm{T}_{b}<1.2 \mathrm{~T}_{p c}
\end{array}\right.
\end{gathered}
$$

In the above equations, $b, w a$, and $p c$ refer to the bulk, wall, and pseudo-critical, respectively. Finally, after calculating the area of each divided section, the overall heat exchanger area can be obtained:

$$
A_{\text {Tot }}=\sum A_{j}
$$

Specific investment cost (SIC) is an economic indicator that presents the total capital to net power ratio of the system and can be defined as follows [55]:

$$
S I C=F_{S} \times \frac{C_{T C I}}{\dot{W}_{\text {net }}}
$$

Here, $F_{S}$ is the correction factor of overhead expenses [55]. The equations of the cost calculation of power plants are presented in Table 7 [55].

Table 7. The total capital investment and production cost [55].

\begin{tabular}{cc}
\hline Cost Item & Correlation \\
\hline Total direct permanent investment & $C_{D P I}=T C_{B}+C_{\text {site }}+C_{\text {serv }}+C_{\text {alloc }}$ \\
Total depreciable capital & $C_{T D C}=C_{D P I}+C_{\text {cont }}$ \\
Cost of contingencies and contractor's fee & $C_{\text {cont }}=0.18 C_{D P I}$ \\
Total permanent investment & $C_{T P I}=C_{T D C}+C_{\text {land }}+C_{\text {royal }}+C_{\text {startup }}$ \\
Total capital investment & $C_{T C I}=C_{T P I}+C_{W C}$ \\
Cost of wages and benefits & $C_{W B}=0.035 C_{T D C}$ \\
Cost of salaries and benefits & $C_{S B}=0.035 C_{W B}$ \\
Cost of materials and services & $C_{M S}=C_{W B}$ \\
Cost of maintenance overhead & $C_{M O}=0.05 C_{W B}$ \\
Direct manufacturing costs & $C_{D M C}=C_{W B}+C_{S B}+C_{M S}+C_{M O}$ \\
Cost of property taxes and liability insurance & $C_{P I}=0.02 C_{T D C}$ \\
Fixed manufacturing costs & $C_{F I X}=C_{P I}$ \\
Total annual cost of manufacture & $C_{C O M}=C_{D M C}+C_{F I X}$ \\
General expenses & $C_{G E}=0$ \\
Total production cost & $C_{T P C}=C_{C O M}+C_{G E}$ \\
\hline
\end{tabular}


The geothermal well drilling cost is calculated as follows [19]:

$$
\text { Well drilling cost }=16.5 \times z^{1.607}
$$

LCOE (levelized cost of energy) is an important economic indicator. Low-cost electricity generation can lead to the investors' lucrativeness in a specific period; this is a proper explanation of a relatively low LCOE value [56]. This can be calculated as [55]:

$$
L C O E=\frac{C_{T C I}+\sum_{t=1}^{n}\left(\frac{C_{T P C}}{(1+i)^{t}}\right)}{\sum_{t=1}^{n}\left(\frac{E_{t}}{(1+i)^{t}}\right)}
$$

where $E_{t}$ is the generated electrical power in year $t(\mathrm{kWh})$. The pay-back period $(P B P)$ is the required time for an energy system to return its investment. It could give investors a better understanding of the risk of their investment. Pay-back time can be written as [55]:

$$
P B P=\frac{C_{T D C}}{\text { Cash flow }}
$$

The pay-back period is calculated according to corporate tax rates and mean electricity prices for Iran's industry. The mathematical modeling flowchart of the system is illustrated in Figure 3.

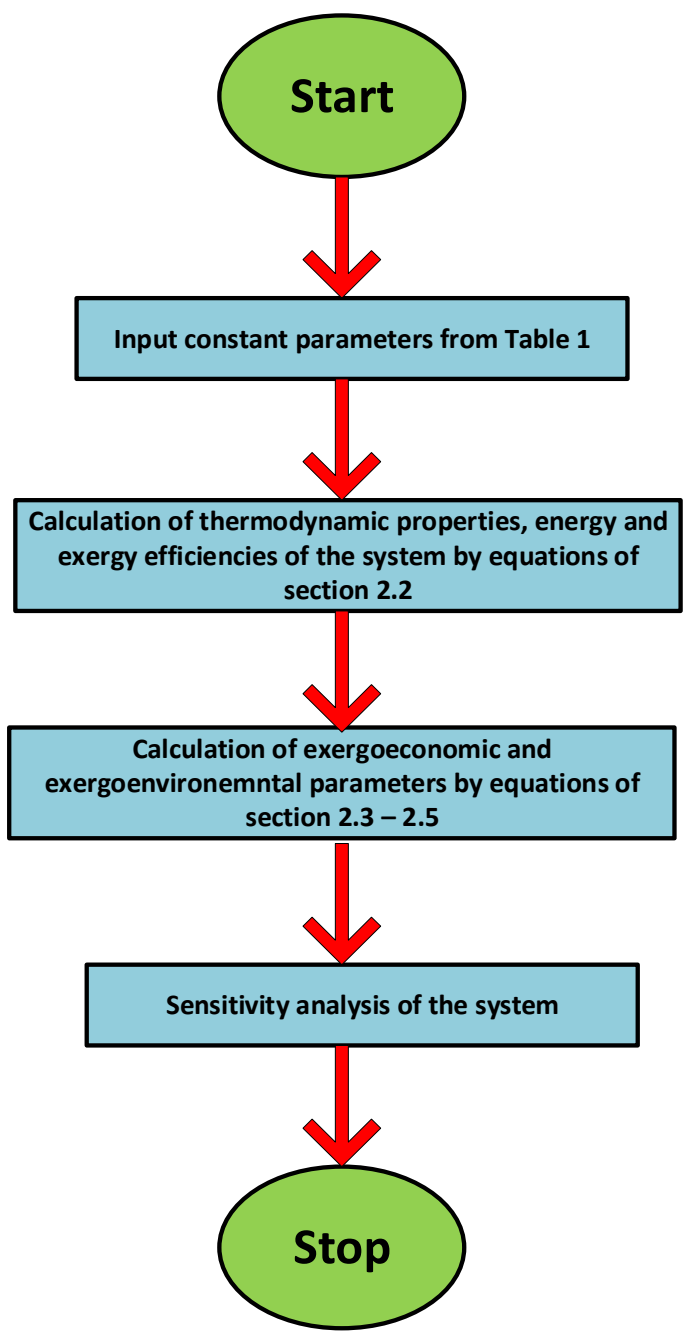

Figure 3. Mathematical modeling flowchart of the system. 


\section{Exergo-Environmental Analysis}

This cycle is compared with conventional fossil fuel power plants, which consume fuels and cause greenhouse gas emissions. As a geothermal power plant does not need fuel to generate electricity and gets its required energy from the geothermal fluid, these advantages, compared with conventional fossil fuel power plants, could be explained by a reduction in fuel consumption and carbon dioxide emissions in a year as follows [57]:

$$
\begin{gathered}
M_{\mathrm{CO}_{2}}=\alpha_{\mathrm{CO}_{2}} \times N \times\left(\frac{\dot{W}_{\text {net }}}{1000}\right) \\
M_{\text {Petro }}=\alpha_{\text {Petro }} \times N \times\left(\frac{\dot{W}_{\text {net }}}{1000}\right)
\end{gathered}
$$

In the above equation, $\alpha_{\text {Petro }}$ is the average needed petroleum for generating $1 \mathrm{kWh}$ of electricity, which is considered as $0.266 \mathrm{~L} / \mathrm{kWh}[10]$, and $\alpha_{\mathrm{CO}_{2}}$ is the amount of released carbon dioxide from fossil fuels for producing $1 \mathrm{kWh}$, which is considered $0.849 \mathrm{~kg} / \mathrm{kWh}$ [10]. These reductions are related to the power plants' user phase and do not include the construction part as geothermal construction has some environmental impacts [58]. The exergoenvironmental indicator presents the systems' evaluation from exergy and environmental aspects and environmental impacts of the irreversibilities. The exergo-environmental impact factor can be calculated as $[59,60]$ :

$$
f_{e i}=\frac{\dot{E} x_{D, T o t}}{\dot{E} x_{i n}}
$$

The exergo-environmental impact index is an indicator that represents how much a system is environmentally damaging. It can be obtained from $[59,60]$ :

$$
\theta_{e i}=\frac{100 \times f_{e i}}{\eta_{e x}}
$$

\section{Multi-Objective Optimization}

The multi-objective optimization was done by the NSGA-II algorithm in MATLAB to obtain the optimum solution. Two objective functions were considered in the optimization process: total cost rate and cycle exergy efficiency. Optimization aims to minimize the cost and maximize efficiency. The selected design variables and their constraints are shown in Table 8. The main parameters of the optimization process are presented in Table 9. The first objective function is exergy efficiency (Equation (11)) and another function is the sum of the capital and exergy destruction cost rate of the components, which is as follows:

$$
\dot{C}_{\text {Tot }}=\dot{Z}_{k}+\dot{C}_{D, k}
$$

Table 8. Design variables and their constraints.

\begin{tabular}{ccc}
\hline Variable & Lower Bound & Upper Bound \\
\hline $\mathrm{T}_{1}(\mathrm{~K})$ & 428 & 448 \\
$P_{2}(\mathrm{kPa})$ & 400 & 600 \\
$\mathrm{~T}_{8}(\mathrm{~K})$ & 395 & 410 \\
$\eta_{F T}(\%)$ & 0.7 & 0.9 \\
$\eta_{O R C T}(\%)$ & 0.7 & 0.9 \\
$\eta_{p}(\%)$ & 0.7 & 0.9 \\
$\eta_{\text {Comp }}(\%)$ & 0.65 & 0.85 \\
$\mathrm{~T}_{23}(\mathrm{~K})$ & 281 & 288 \\
$\mathrm{~T}_{25}(\mathrm{~K})$ & 318 & 328 \\
\hline
\end{tabular}


Table 9. Parameters of the optimization process.

\begin{tabular}{cc}
\hline Parameter & Value \\
\hline Selection function & Tournament \\
Maximum generation size & 200 \\
Population & 100 \\
Mutation & 0.7 \\
Crossover & 0.3 \\
\hline
\end{tabular}

\section{Results and Discussion}

\subsection{Solution Procedure and Model Validation}

Energy, exergy, economic, and environmental evaluation of a flash-binary geothermal CCHP power plant was carried out in the present research. A sensitivity evaluation of the input temperature of the production well and cooling to power flow ratio on the cycle's exergetic and economic performance was done. Furthermore, the effects of interest rate and plant working hours on economic parameters were evaluated. The thermodynamic and exergoeconomic modeling was expanded in MATLAB using Refprop 9.1. Multi-objective optimization was carried out by the NSGA-II algorithm to find the best solution and value. The code was compared with a flash-binary cycle investigated by Wang et al. [31] and Kolahi et al. [61] to validate the modeling. The results showed that the present calculation had good compatibility with their results, which are shown in Table 10. The errors were mostly because of the database using thermodynamic properties in Refprop.

Table 10. Comparison of our results with Wang et al. [31] and Kolahi et al. [61].

\begin{tabular}{ccccccc}
\hline Parameter & Wang et al. & $\begin{array}{c}\text { Our } \\
\text { Result }\end{array}$ & Error & Kolahi et al. & $\begin{array}{c}\text { Our } \\
\text { Result }\end{array}$ & Error \\
\hline $\mathrm{T}_{3}\left({ }^{\circ} \mathrm{C}\right)$ & 151.83 & 151.82 & $0.006 \%$ & 155.5 & 156.1 & $0.38 \%$ \\
$\mathrm{~T}_{9}\left({ }^{\circ} \mathrm{C}\right)$ & 64.52 & 64.02 & $0.77 \%$ & 58.2 & 58.9 & $1.2 \%$ \\
$\mathrm{~T}_{13}\left({ }^{\circ} \mathrm{C}\right)$ & 87.83 & 86.9 & $1.05 \%$ & - & - & - \\
$h_{9}(\mathrm{~kJ} / \mathrm{kg})$ & 490.34 & 488.1 & $0.46 \%$ & 619.03 & 621.4 & $0.38 \%$ \\
$h_{17}(\mathrm{~kJ} / \mathrm{kg})$ & 1757.79 & 1734.9 & $1.28 \%$ & - & - & - \\
$\dot{W}_{\text {net }}(\mathrm{kW})$ & 4186.48 & 4169.3 & $0.41 \%$ & 5724 & 5786 & $1.08 \%$ \\
$\eta_{\text {ex }}(\%)$ & 30.49 & 30.07 & $1.37 \%$ & 59.51 & 59.82 & $0.52 \%$ \\
\hline
\end{tabular}

\subsection{Optimization Results}

The obtained Pareto frontier curve is illustrated in Figure 4. As can be seen, five different points were selected on this graph. Each Pareto point could be an optimum solution for selecting the final optimum point related to decision-maker opinion in a multiobjective optimization solution. Among these points, points B, C, D, and E had higher efficiency and points $A, B$, and $C$ had lower cost rate values than the base case. Point $C$ was selected as the optimum point for this optimization solution, which had a $4.5 \%$ higher efficiency and $10.3 \%$ lower cost rate than the base case. The values of the objective functions and design variables for all selected points are presented in Table 11. 


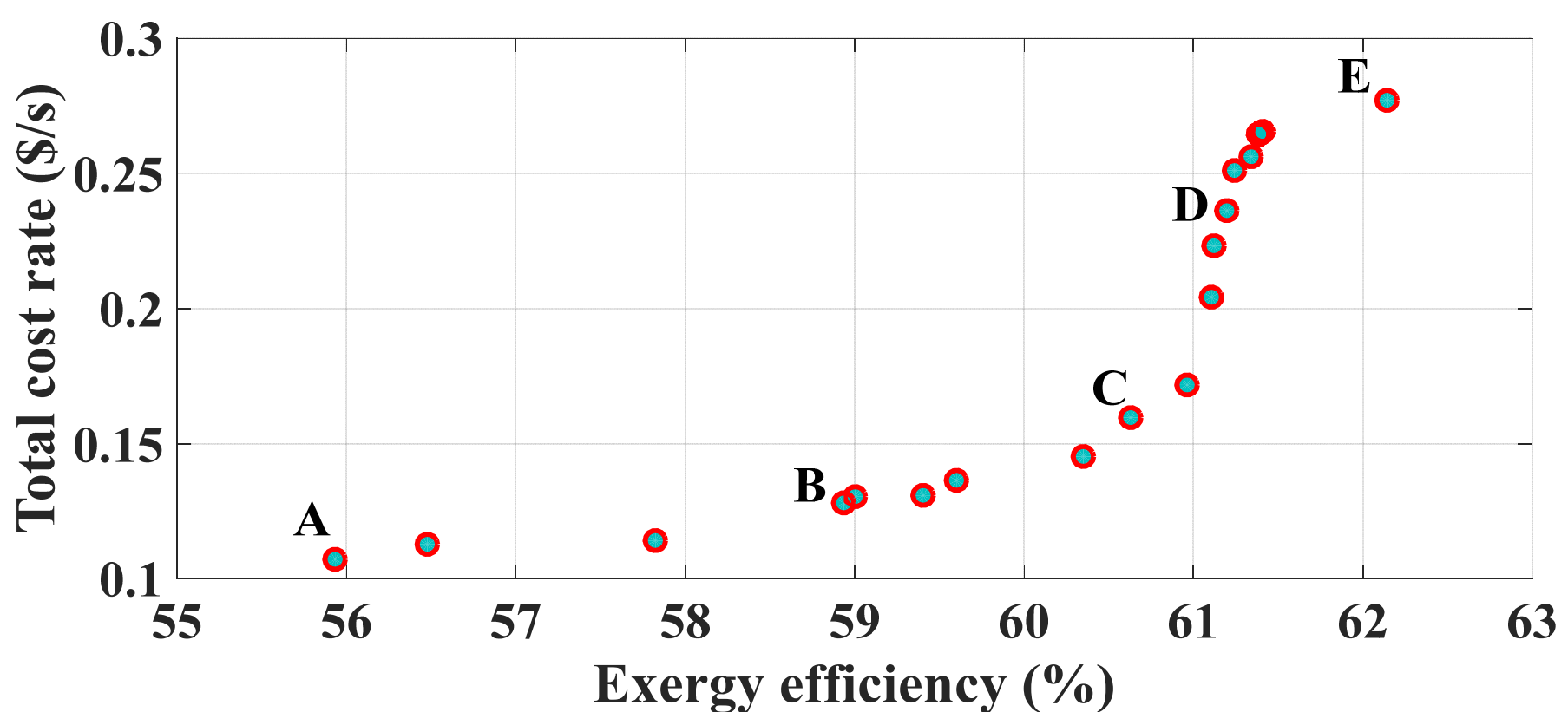

Figure 4. Pareto frontier curve.

Table 11. The values of the objective functions and design variables at selected points of the Pareto curve.

\begin{tabular}{cccccc}
\hline Parameter & A & B & C & D & E \\
\hline$\eta_{e x}(\%)$ & 55.93 & 58.93 & 60.63 & 61.2 & 62.14 \\
$\dot{C}_{\text {Tot }}(\$ / \mathrm{s})$ & 0.1072 & 0.1282 & 0.1599 & 0.2364 & 0.2769 \\
$\mathrm{~T}_{1}(\mathrm{~K})$ & 445.8 & 444.3 & 439.5 & 433.3 & 430.6 \\
$P_{2}(\mathrm{kPa})$ & 423.6 & 431.9 & 437.7 & 451.7 & 448.6 \\
$\mathrm{~T}_{8}(\mathrm{~K})$ & 406.5 & 405.2 & 405.2 & 404.6 & 406.1 \\
$\eta_{F T}(\%)$ & 88.4 & 87.4 & 88.8 & 88.8 & 86.9 \\
$\eta_{O R C T}(\%)$ & 79.4 & 86.5 & 88.3 & 88.8 & 89.7 \\
$\eta_{p}(\%)$ & 79.3 & 74.9 & 78.6 & 82.3 & 86.5 \\
$\eta_{\text {Comp }}(\%)$ & 71.5 & 72.2 & 71.9 & 78.2 & 72.8 \\
$\mathrm{~T}_{23}(\mathrm{~K})$ & 286.2 & 284.4 & 285.9 & 284.4 & 285.9 \\
$\mathrm{~T}_{25}(\mathrm{~K})$ & 324.4 & 324.3 & 324.3 & 323.7 & 324.4 \\
\hline
\end{tabular}

\subsection{Results of the Analyses}

The thermodynamic properties of the evaluated power plant are shown in Table 12 and the main calculated parameters in both the base and optimum cases are presented in Table 13. The exergoeconomic variables of the cycle are shown in Table 14. Figure 5a illustrates the exergy efficiency and destruction changes against the production well inlet temperature. Regarding the results, increasing the production temperature well raises the exergy efficiency slightly at first, then decreases, and the decreasing trend has more slope at higher temperatures as irreversibilities increase. Exergy destruction had slight changes with a slight reduction at first up to $430 \mathrm{~K}$, then increased. Raising the production well temperature increases the heat input into the system, which is more dominant at lower temperatures. However, more temperature enhancement causes a growth in the irreversibilities of the system.

The variations of EPC and exergo-environmental impact are presented in Figure $5 \mathrm{~b}$. Regarding this figure, raising the inlet temperature of the cycle causes a decrease in exergetic performance and an increase in the exergo-environmental index. A decline in $E P C$ was due to the diminished net produced work and growth in the exergy destruction with the inlet temperature of the production well rising. Temperature increase from 428 to $448 \mathrm{~K}$ caused a decrease in $E P C$, diminishing from 1.99 to 1.91. This trend for the exergo- 
environmental index is converse; it increased from 0.502 to 0.524 in this temperature range. Increase in the exergo-environmental index is mainly due to decreased exergy efficiency, which means an increase in the destruction.

Table 12. The thermodynamic properties of the cycle.

\begin{tabular}{cccccc}
\hline Point & $\mathbf{T}(\mathbf{K})$ & $\boldsymbol{P}(\mathbf{k P a})$ & $\boldsymbol{h} \mathbf{( \mathbf { k J } / \mathbf { k g } )}$ & $\boldsymbol{s} \mathbf{( k J / k g K )}$ & $\boldsymbol{e x} \mathbf{( k J} / \mathbf{k g})$ \\
\hline 1 & 443.2 & 900 & 719.36 & 2.042 & 115.09 \\
2 & 424.9 & 500 & 719.36 & 2.046 & 113.63 \\
3 & 424.9 & 500 & 640.08 & 1.860 & 89.97 \\
4 & 333.2 & 19.9 & 251.38 & 0.831 & 7.91 \\
5 & 424.9 & 500 & 2748.10 & 6.820 & 719.09 \\
6 & 333.2 & 19.9 & 2322.02 & 7.046 & 225.72 \\
7 & 328.2 & 15.8 & 230.46 & 0.768 & 5.84 \\
8 & 409.9 & 3512.3 & 525.94 & 1.465 & 138.88 \\
9 & 310.6 & 354.4 & 452.27 & 1.508 & 52.59 \\
11 & 303.2 & 354.4 & 85.77 & 0.300 & 46.33 \\
12 & 305.2 & 3512.3 & 92.53 & 0.304 & 51.76 \\
14 & 303.2 & 354.4 & 85.77 & 0.300 & 46.33 \\
15 & 280.1 & 169.9 & 85.77 & 0.308 & 43.74 \\
16 & 280.1 & 169.9 & 409.57 & 1.464 & 22.94 \\
17 & 308.6 & 354.4 & 448.59 & 1.496 & 52.45 \\
18 & 310.1 & 354.4 & 451.33 & 1.505 & 52.55 \\
19 & 303.2 & 354.4 & 85.77 & 0.300 & 46.33 \\
20 & 298.2 & 101.3 & 298.49 & 6.860 & 0 \\
21 & 308.2 & 101.3 & 308.56 & 6.893 & 0.16 \\
22 & 298.15 & 101.3 & 104.92 & 0.367 & 0 \\
23 & 281.15 & 101.3 & 33.72 & 0.121 & 2.11 \\
24 & 298.15 & 101.3 & 105.13 & 0.367 & 0 \\
25 & 323.2 & 101.3 & 209.62 & 0.704 & 4.16 \\
\hline
\end{tabular}

Table 13. The main calculated parameters of the cycle.

\begin{tabular}{cccccc}
\hline Parameter & Base Case & Optimum & Parameter & Base Case & Optimum \\
\hline$\eta_{t h}(\%)$ & 11.02 & 11.41 & $L C O E(\mathrm{c} \$ / \mathrm{kWh})$ & 6.54 & 6.22 \\
$\eta_{e x}(\%)$ & 58.01 & 60.63 & $\dot{Q}_{\text {Eva } 1}(\mathrm{~kW})$ & $37,407.7$ & 35,274 \\
$\dot{W}_{\text {net }}(\mathrm{kW})$ & 6222.4 & 6183 & $\dot{Q}_{\text {Eva } 2}(\mathrm{~kW})$ & 9583.6 & 8920.4 \\
$\dot{C}_{\text {Tot }}(\$ / \mathrm{s})$ & 0.1764 & 0.1599 & $\dot{Q}_{H X}(\mathrm{~kW})$ & 7865.7 & 8295.4 \\
$C O P$ & 8.3 & 7.95 & $\dot{Q}_{\text {Cond }}(\mathrm{kW})$ & $42,371.3$ & 39,709 \\
\hline
\end{tabular}

Table 14. The exergo-economic parameters of the system.

\begin{tabular}{|c|c|c|c|c|c|c|}
\hline Component & $\dot{Z}_{k}(\mathrm{US} \$ / \mathrm{s})$ & $\begin{array}{c}\dot{C}_{D, k} \\
\text { (US\$/s) }\end{array}$ & $\begin{array}{c}\dot{Z}_{k}+\dot{C}_{D, k} \\
\text { (US\$/s) }\end{array}$ & $\begin{array}{c}P E C \\
\text { (US\$/s) }\end{array}$ & $\eta_{e x, k}(\%)$ & $f_{k}(\%)$ \\
\hline$E V 1$ & 0.000127 & 0.000356 & 0.000483 & $17,513.3$ & 98.7 & 26.3 \\
\hline Sep & 0.000068 & 0 & 0.000068 & 9379.6 & 100 & 100 \\
\hline Eva 1 & 0.015355 & 0.000937 & 0.016293 & $2,118,496.7$ & 95.2 & 94.2 \\
\hline$F T$ & 0.017627 & 0.000627 & 0.018255 & $2,432,022.3$ & 86.4 & 96.6 \\
\hline$H X$ & 0.001220 & 0.002050 & 0.003271 & $168,370.5$ & 37.9 & 37.3 \\
\hline ORCT & 0.017628 & 0.010326 & 0.027954 & $2,432,022.3$ & 85.4 & 63.1 \\
\hline Cond & 0.004943 & 0.065226 & 0.070169 & $681,972.3$ & 62.5 & 7.0 \\
\hline Pump & 0.002026 & 0.001582 & 0.003608 & $279,539.6$ & 80.4 & 56.2 \\
\hline$E V 2$ & 0.000038 & 0.001310 & 0.001348 & 5183.6 & 94.4 & 2.8 \\
\hline Eva 2 & 0.009244 & 0.012175 & 0.021419 & $1,275,396.8$ & 46.2 & 43.1 \\
\hline Comp & 0.009654 & 0.003905 & 0.013559 & $1,331,975.1$ & 75.6 & 71.2 \\
\hline Mixer & 0 & 0 & 0 & 0 & 100 & 0 \\
\hline
\end{tabular}



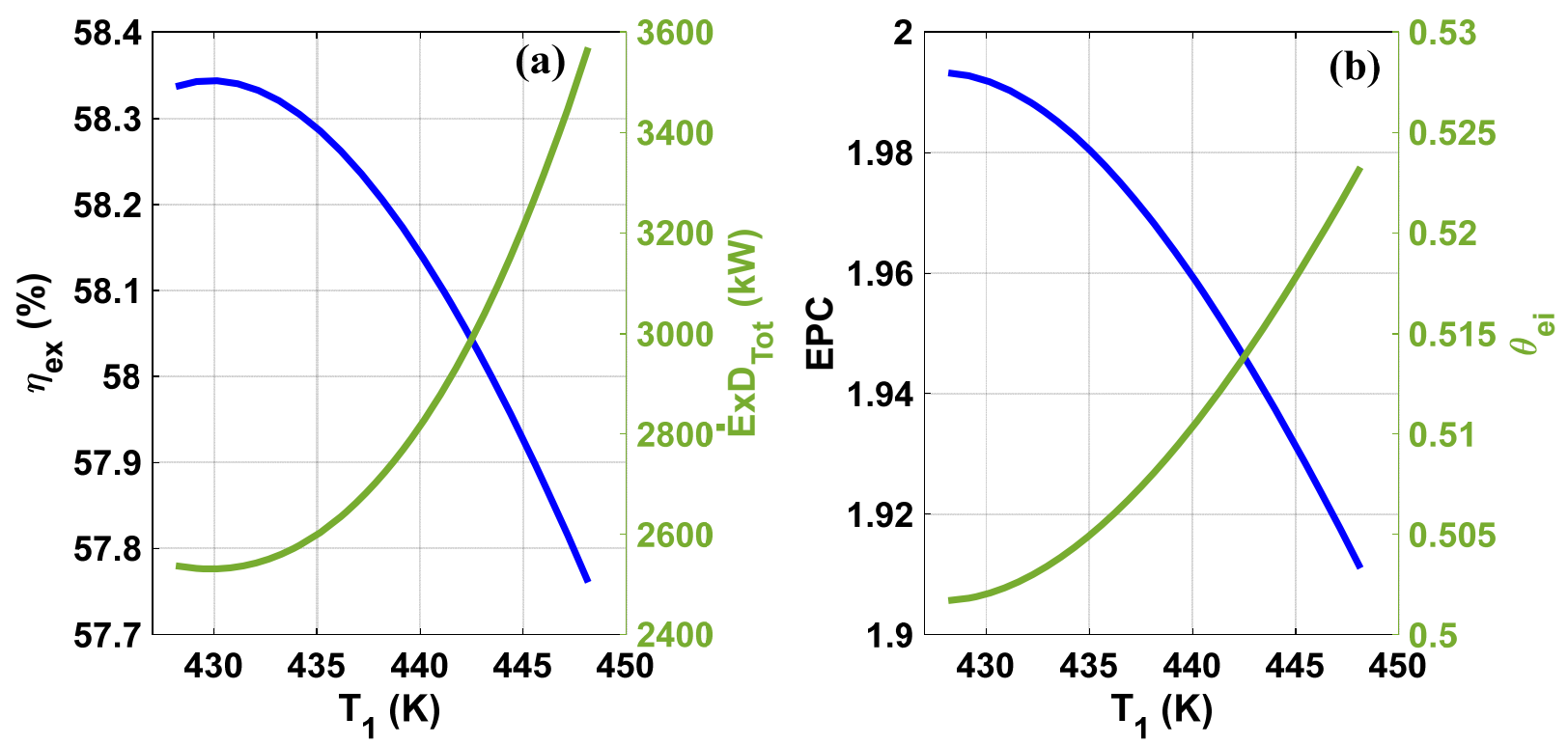

Figure 5. (a) The exergy efficiency and destruction variations with the inlet temperature of the production well. (b) The exergetic performance criteria and exergo-environmental impact index variations with the inlet temperature of the production well.

Figure 6a depicts the total plant cost and SIC variations against the inlet temperature of the production well. It is clear that increasing the inlet temperature of the production well led to a rise in total plant cost, mainly related to an increase in purchasing cost of some components. Additionally, raising the inlet temperature of the production well increased the SIC first (from 3.94 at $428 \mathrm{~K}$ to 4.28 at $436 \mathrm{~K}$ ), and after reaching its maximum value at $436 \mathrm{~K}$, it decreased to $4.08 \$ / \mathrm{W}$ at $448 \mathrm{~K}$. At lower temperatures, the total cost increased as the temperature increased. This is the main factor in SIC growth; however, at higher temperatures, the produced power cost changes with more than lower temperatures, leading to a decrease in SIC. The production and produced electricity cost rate variations with the inlet temperature of production well increase is shown in Figure 6b. According to the obtained results, enhancing the cycle inlet temperature decreases the heat capacity of evaporator 2, which means a reduction in the cycle's cooling capacity. Furthermore, this temperature growth leads to the heat capacity enhancement of the heat exchanger and hot water production. Temperature growth directly impacts the heat exchanger capacity as it increases the system's input energy.

Figure 7a displays the exergy efficiency and destruction of the cycle changes vs. cooling to power flow ratio. According to this figure, increasing this ratio causes a decline in cycle exergy efficiency and an enhancement in exergy destruction. It can be found from the results that increasing the cooling to power rate has a significant negative impact on the exergetic performance of the system, so that by raising $\alpha$ from 0.1 to 0.9 , the exergy efficiency lessens from $64 \%$ to $20 \%$, and exergy destruction grows from 2900 to $5600 \mathrm{~kW}$. This negative effect is related to reducing net produced power with increasing $\alpha$ that reduces the system's efficiency and productivity. As the cooling to power flow ratio values change, the mass flow rate of division and its changes are constantly increasing, then the exergy efficiency and destructive behavior are linear. The effect of the cooling to power flow ratio on EPC and the exergo-environmental impact index is illustrated in Figure $7 \mathrm{~b}$. Exergetic performance declines with a gain in the cooling to power flow ratio, which is due to an increase in destruction. Moreover, as the destruction increases, the exergo-environmental impact index increases, which negatively affects the environment. 

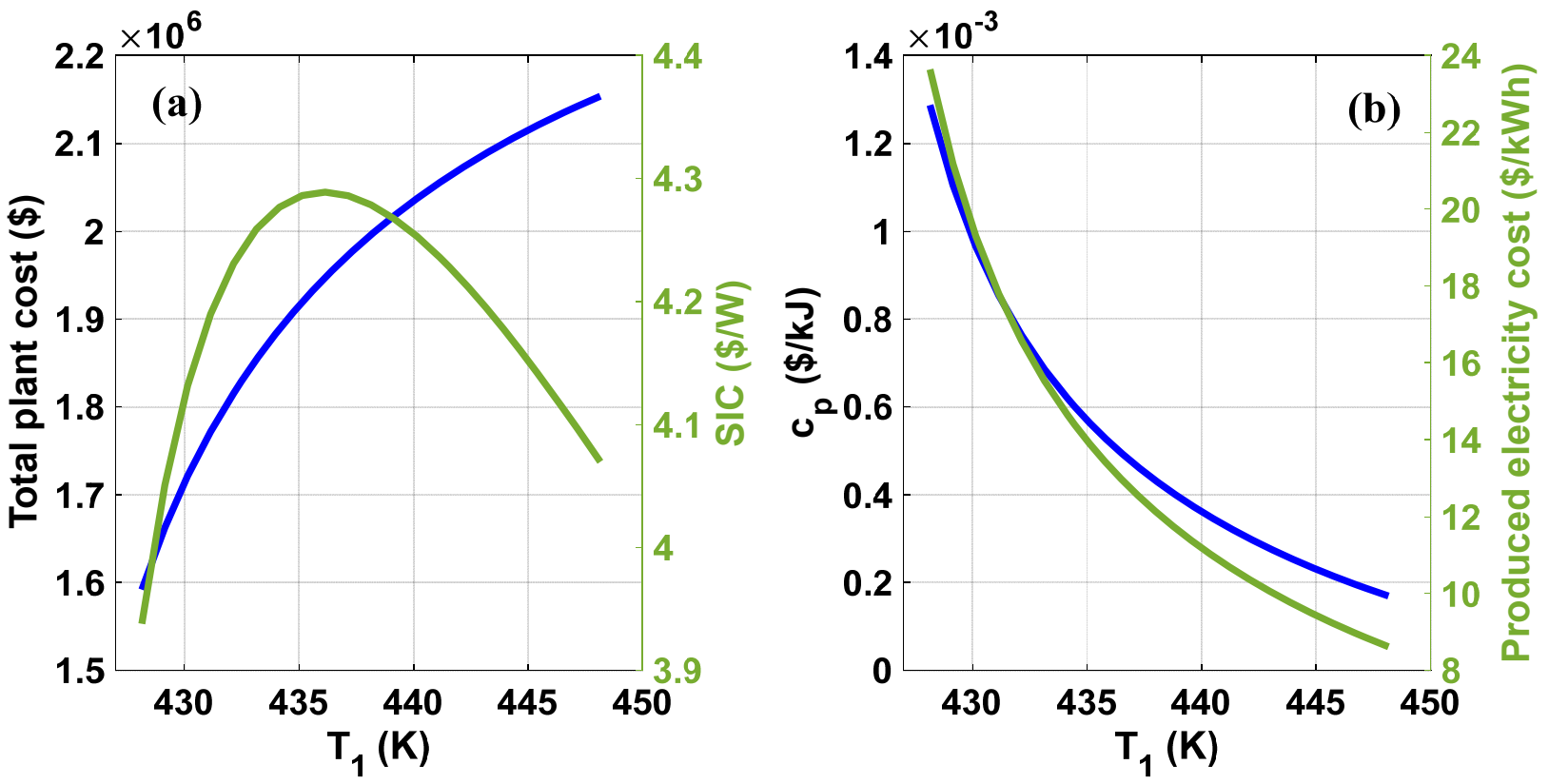

Figure 6. (a) The total plant cost and specific investment cost variations with the inlet temperature of production well. (b) Production and produced electricity cost rate variations against the production well inlet temperature.
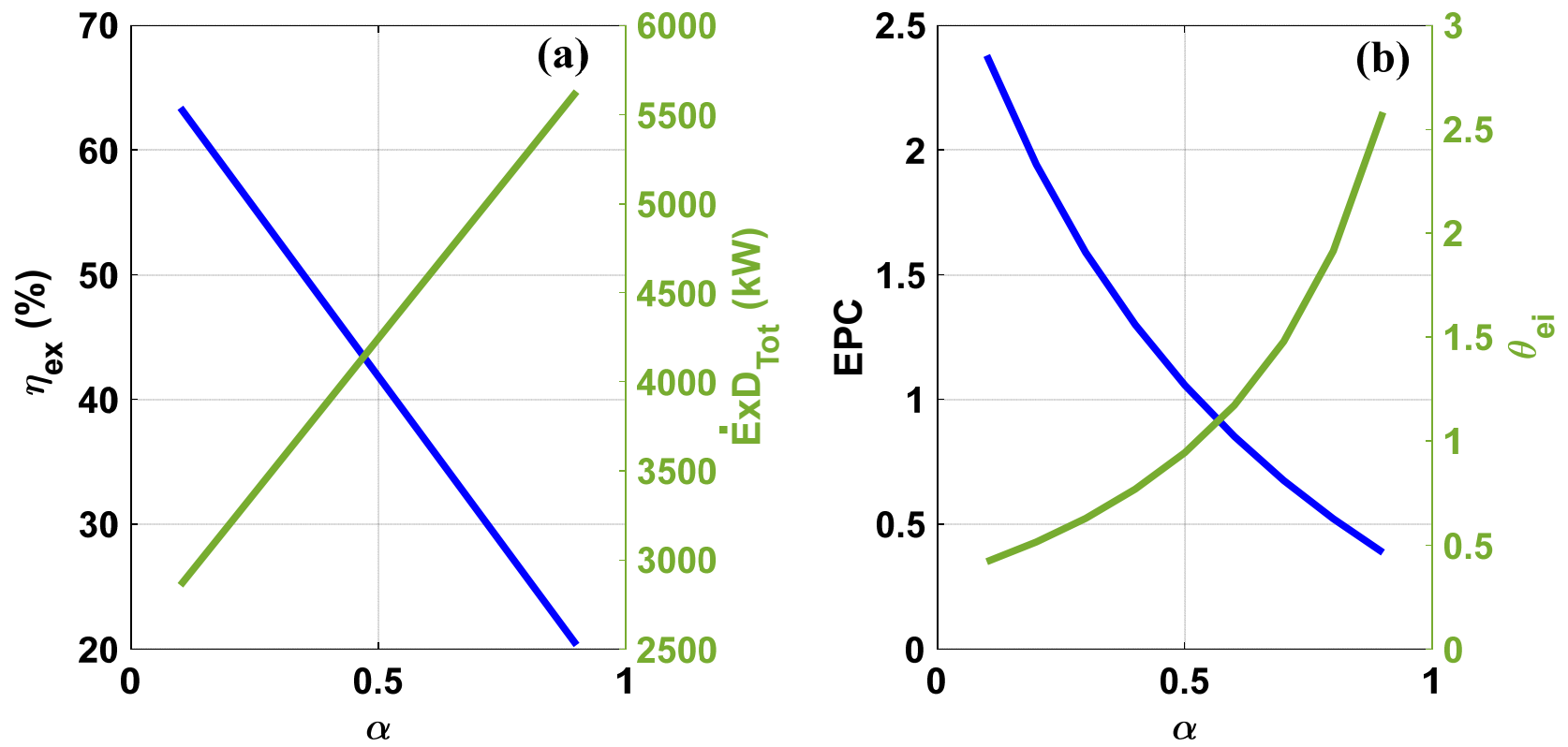

Figure 7. (a) Exergy efficiency and destruction variations against cooling to power flow ratio. (b) The exergetic performance criteria and exergo-environmental impact index variations with cooling to power flow ratio.

Figure 8a presents the total plant cost and SIC variations vs. cooling to power flow ratio. It is straightforward that both total plant cost and specific investment cost increase with the rising cooling to power flow ratio. Increasing the cooling to power flow ratio causes growth in the compressor capacity, and consequently more expensive equipment. SIC growth is mainly related to a rise in plant cost and reduction in net produced power. Figure $8 \mathrm{~b}$ shows the evaporator 2 heat and net produced power of the cycle changes vs. cooling to power flow ratio. Evaporator 2 heat capacity increases, and net power reduces with cooling to power flow ratio enhancement. Increasing evaporator 2 heat is due to a rise in the evaporator mass flow rate with rising $\alpha$. However, as increasing the cooling side mass flow rate increases the required compressor work, then the network declines. The 
variations in exergy destruction cost rate and LCOE against interest rate percentage are shown in Figure 9a. It can be seen that the growth in the rate of interest harms both the exergy destruction cost rate and $L C O E$, so that increasing the interest rate from $10 \%$ to $15 \%$ leads to an increase in the exergy destruction cost rate from 0.055 to $0.13 \$ / \mathrm{s}$ and $L C O E$ from 4.3 to $8 \mathrm{c} \$ / \mathrm{kWh}$. Figure $9 \mathrm{~b}$ depicts the effect of the interest rate change on production and the total cost rate. Results show that both the production and total cost rate increase with the growth in interest rate.
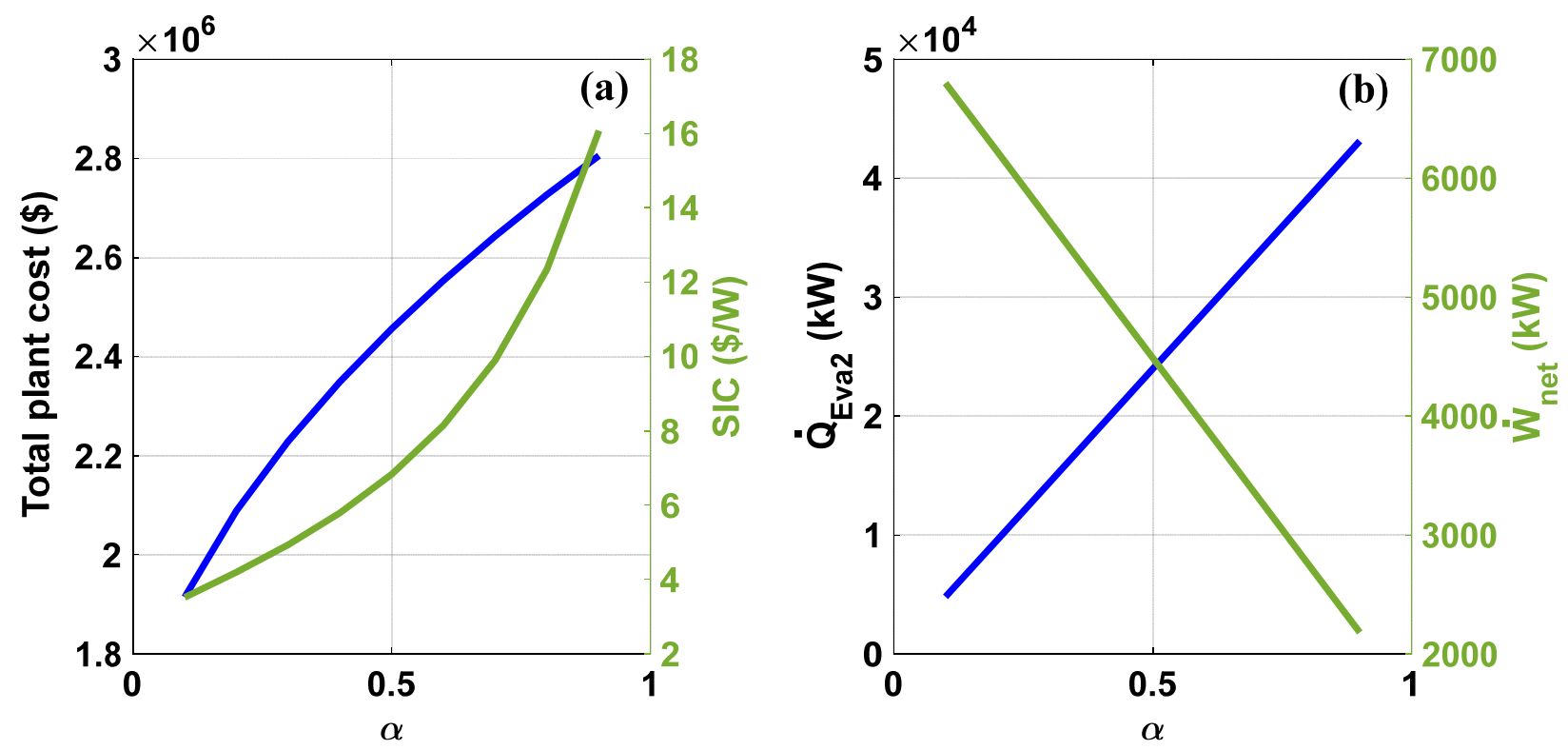

Figure 8. (a) The total plant cost and specific investment cost variations with cooling to power flow ratio. (b) The evaporator 2 and net power variations with cooling to power flow ratio.
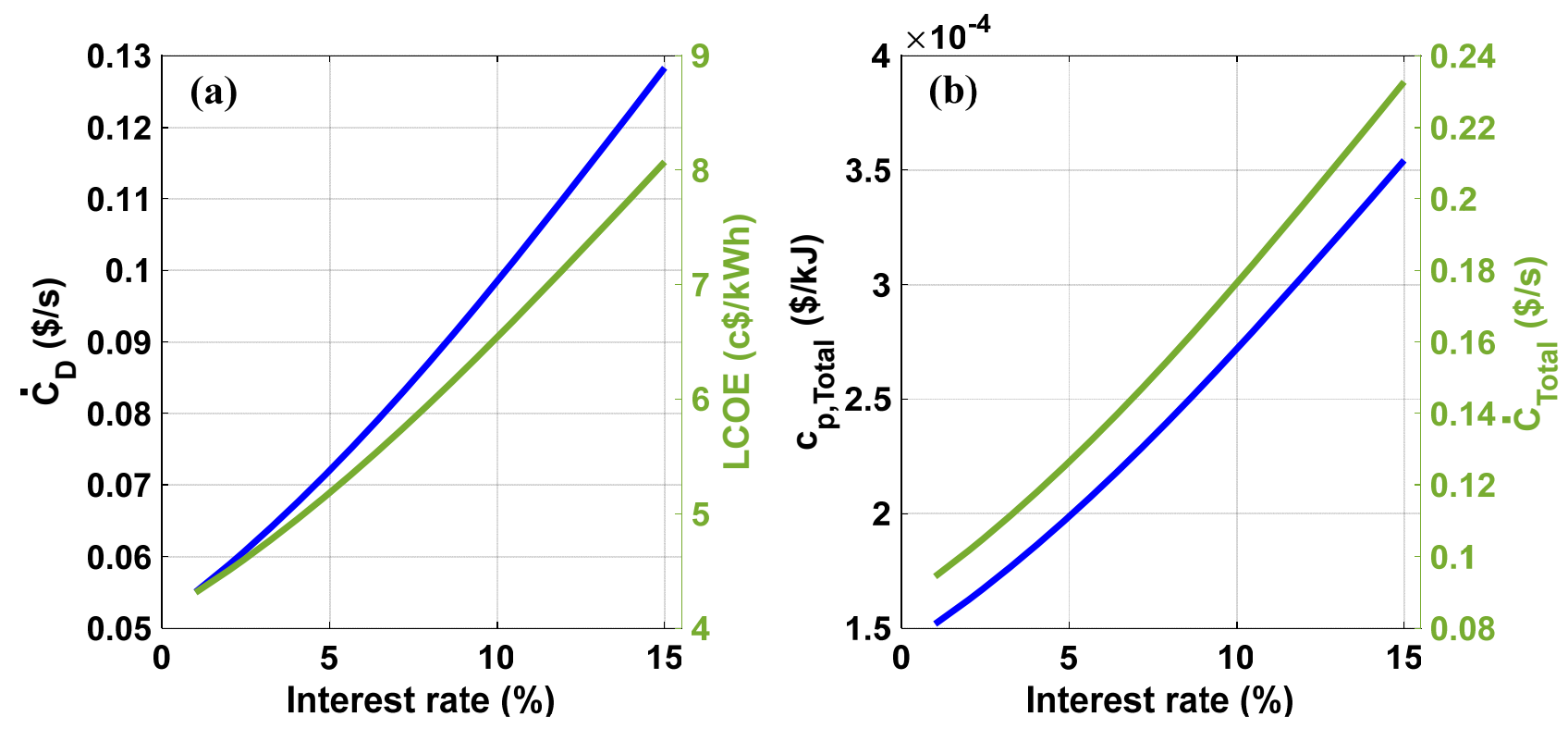

Figure 9. (a) Exergy destruction cost and levelized cost of energy variations against interest rate. (b) Production and total cost rate variations against interest rate.

Figure 10a illustrates the exergy destruction cost rate and $L C O E$ variations vs. the working hours of the power plant. It is clear from this graph that enhancement in working hours results in a decrease in both the exergy destruction cost rate and LCOE. The impact of the plant's working hours on the production and total cost rate is presented in Figure 10b. 
It is clear that the production and total cost rate have increased with the rising working hours of the plant.
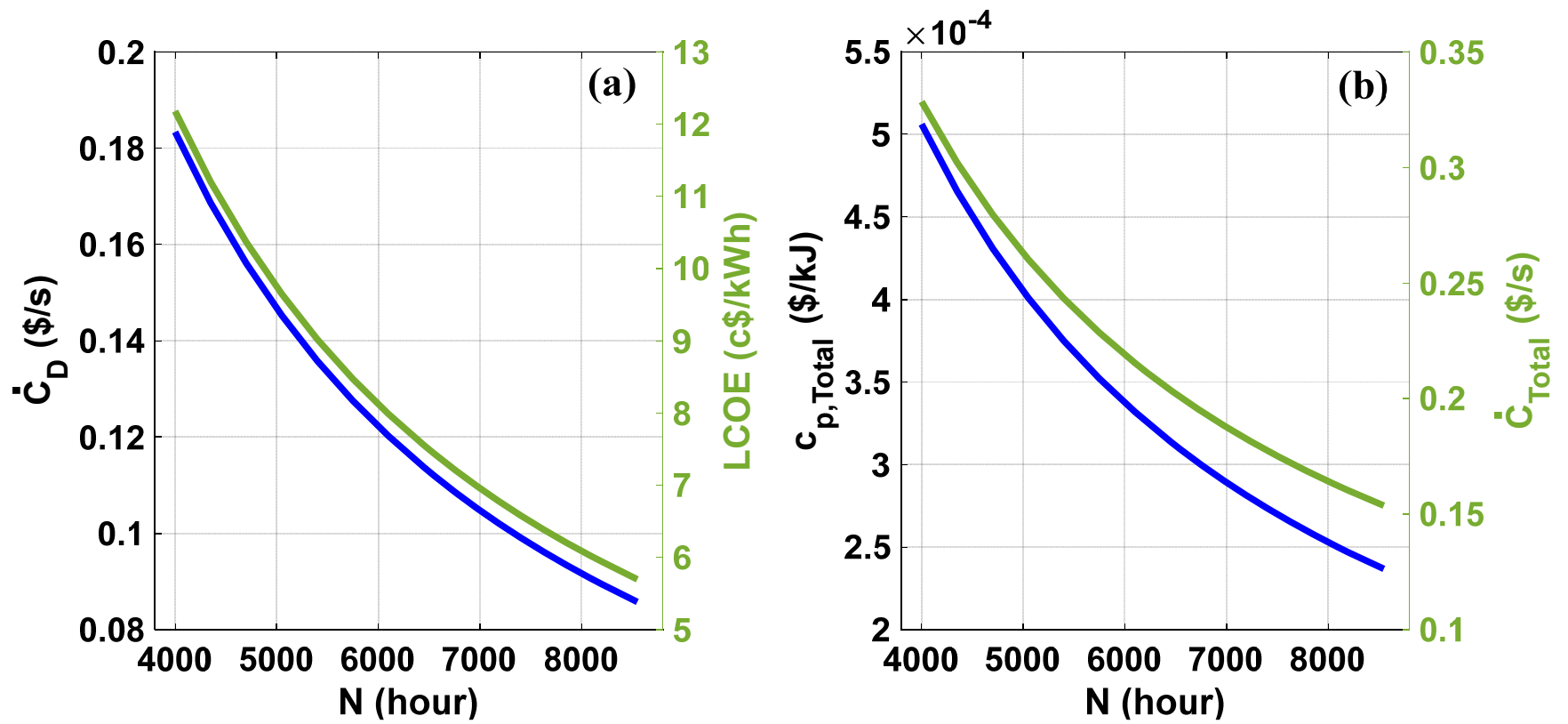

Figure 10. (a) Exergy destruction cost and levelized cost of energy variations against plant working hours. (b) Production and total cost rate variations against power plant working hours.

The exergy destruction ratio of all components is presented in Figure 11. From this graph, the highest value of the destruction of exergy is related to the ORC turbine, which was $34 \%$, and the lowest destruction was related to the separator and mixer. This cycle's pay-back time was about 3.66 years, which was reduced to 3.43 years by optimizing the cycle. The amount of saved $\mathrm{CO}_{2}$ and fuel in this cycle were 39,336 tonnes and 12,324.3 $\mathrm{m}^{3}$ during the lifetime of the power plant, respectively.

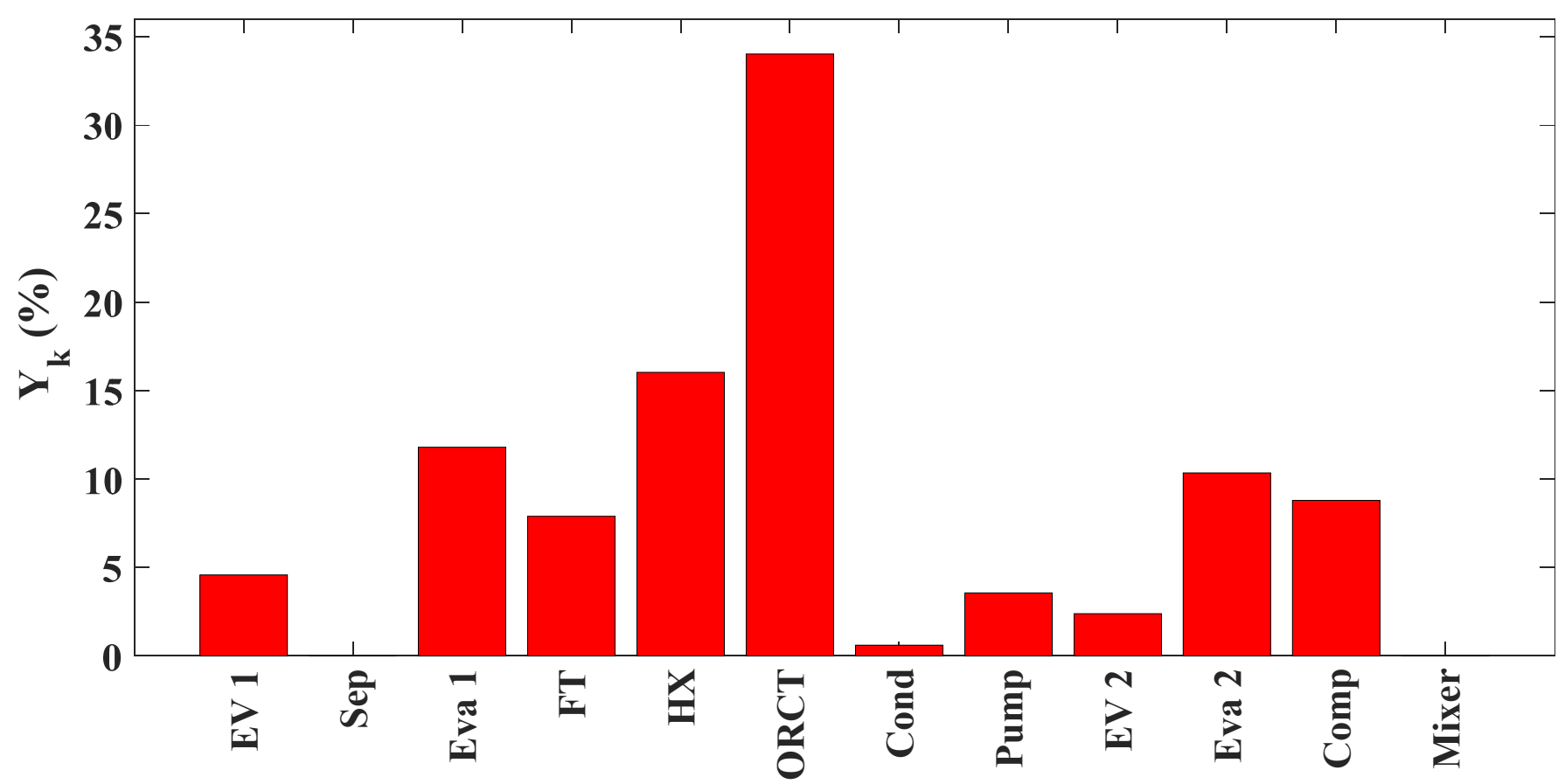

Figure 11. The exergy destruction ratio of all equipment. 


\section{Conclusions}

In this study, energetic, exergetic, exergo-economic, and exergo-environmental analyses of a flash-binary geothermal multi-generation system were conducted to generate power, heating, and cooling. According to the first and second laws of thermodynamic and exergo-economic concepts, the system modeling was extended in MATLAB. Multi-objective optimization was done by the NSGA-II algorithm to find the best design variables and objective function values. A sensitivity analysis of the inlet temperature of the production well and cooling to power flow ratio on exergetic, economic, and environmental parameters were studied. Furthermore, the effects of interest rate and plant working hours on economic parameters were evaluated. The brief obtained conclusions of this study are as follows:

- The optimization results showed that at the selected optimum point, exergy efficiency was $4.5 \%$ higher, and the total cost rate was $10.3 \%$ lower than the base case.

- Growth in the production well's inlet temperature decreased the exergy efficiency, exergetic performance criteria, and cooling capacity. In addition, it harmed the exergoenvironmental index. However, it increased the heating capacity and total plant cost of the cycle. The specific investment cost rose at first, and after reaching its maximum value at $436 \mathrm{~K}$, it was reduced.

- Raising the cooling to power flow ratio reduced the exergy efficiency, exergetic performance, and net power of the system as the irreversibilities rose. However, it increased the exergy destruction, total plant cost, exergo-environmental index, cooling capacity, and specific investment cost.

- Increasing the interest rate caused a rise in exergy destruction, total cost rate, and $L C O E$. Evaluation of the increase in the plant working hours showed a reduction in exergy destruction, production and total cost rate, and LCOE.

- The saved $\mathrm{CO}_{2}$ and petroleum amounts were about 39,336 tonnes and $12,324.3 \mathrm{~m}^{3}$ during the lifetime of the power plant due to use of the geothermal energy as a heat source instead of fossil fuel-based power plants. These reductions are related to the user phase of the power plants.

- The most considerable portion of exergy destruction pertained to the ORC turbine; after that, $H X$ and evaporator 1 had the most destructions.

- The $L C O E$ in the optimization state was $5.14 \%$ lower than the base case. Furthermore, optimization reduced the pay-back period by $6.7 \%$ compared with the base case (Reduced from 3.66 to 3.43 years).

Author Contributions: Data curation, M.S. and M.A.; Formal analysis, M.S.; Methodology, M.S.; Project administration, M.A.; Validation, M.A. and F.T.-H.; Supervision, M.A.; Writing—original draft, M.S. and M.A.; Writing-Review \& editing, F.T.-H. All authors have read and agreed to the published version of the manuscript.

Funding: This research received no external funding.

Conflicts of Interest: The authors declare no conflict of interest.

\section{Nomenclature}

$\begin{array}{ll}A & \text { Area, }\left(\mathrm{m}^{2}\right) \\ c & \text { Specific exergy cost, }(\$ / \mathrm{kJ}) \\ \dot{C} & \text { Cost rate associated with exergy transfer, }(\$ / \mathrm{s}) \\ C O P & \text { Coefficient of Performance } \\ C H P & \text { Combined heat and power } \\ C C H P & \text { Combined cooling heating and power } \\ C R F & \text { Capital Recovery Factor } \\ e x & \text { Specific exergy, }(\mathrm{kJ} / \mathrm{kg}) \\ \dot{E} x & \text { Exergy rate, }(\mathrm{kW}) \\ \dot{E} x D & \text { Exergy destruction }(\mathrm{kW})\end{array}$




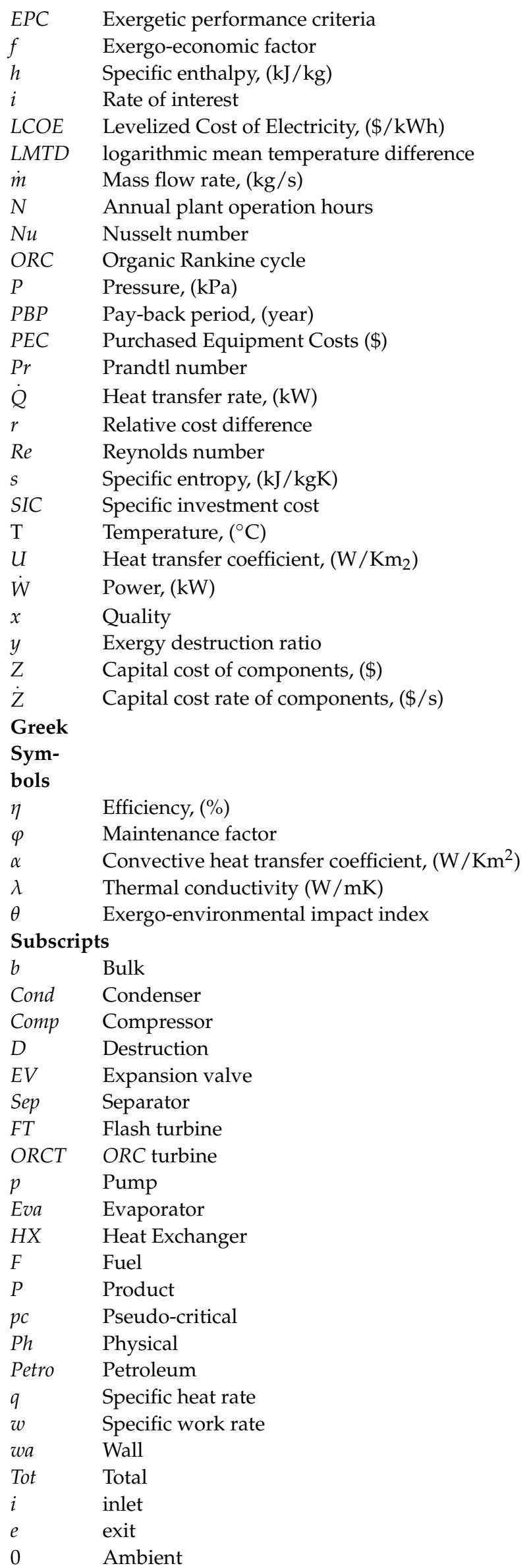




\section{References}

1. Aneke, M.; Agnew, B.; Underwood, C. Performance analysis of the Chena binary geothermal power plant. Appl. Therm. Eng. 2011, 31, 1825-1832. [CrossRef]

2. Khosravi, A.; Syri, S.; Zhao, X.; Assad, M.E.H. An artificial intelligence approach for thermodynamic modeling of geothermal based-organic Rankine cycle equipped with solar system. Geothermics 2019, 80, 138-154. [CrossRef]

3. Ebrahimi, M.; Keshavarz, A.; Jamali, A. Energy and exergy analyses of a micro-steam CCHP cycle for a residential building. Energy Build. 2012, 45, 202-210. [CrossRef]

4. Ahmadi, P.; Dincer, I.; Rosen, M.A. Performance assessment and optimization of a novel integrated multigeneration system for residential buildings. Energy Build. 2013, 67, 568-578. [CrossRef]

5. Al-Ali, M.; Dincer, I. Energetic and exergetic studies of a multigenerational solar-geothermal system. Appl. Therm. Eng. 2014, 71, 16-23. [CrossRef]

6. Aliehyaei, M.; Atabi, F.; Khorshidvand, M.; Rosen, M.A. Exergy, economic and environmental analysis for simple and combined heat and power IC engines. Sustainability 2015, 7, 4411-4424. [CrossRef]

7. Chaiyat, N.; Kiatsiriroat, T. Analysis of combined cooling heating and power generation from organic Rankine cycle and absorption system. Energy 2015, 91, 363-370. [CrossRef]

8. Darvish, K.; Ehyaei, M.A.; Atabi, F.; Rosen, M.A. Selection of optimum working fluid for organic rankine cycles by exergy and exergy-economic analyses. Sustainability 2015, 7, 15362-15383. [CrossRef]

9. Imran, M.; Usman, M.; Park, B.-S.; Yang, Y. Comparative assessment of organic Rankine cycle integration for low temperature geothermal heat source applications. Energy 2016, 102, 473-490. [CrossRef]

10. Zhao, Y.; Wang, J. Exergoeconomic analysis and optimization of a flash-binary geothermal power system. Appl. Energy 2016, 179, 159-170. [CrossRef]

11. Haghighi, A.; Pakatchian, M.R.; Assad, M.E.H.; Duy, V.N.; Nazari, M.A. A review on geothermal organic Rankine cycles: Modeling and optimization. J. Therm. Anal. Calorim. 2021, 144, 1799-1814. [CrossRef]

12. Anvari, S.; Taghavifar, H.; Parvishi, A. Thermo- economical consideration of Regenerative organic Rankine cycle coupling with the absorption chiller systems incorporated in the trigeneration system. Energy Convers. Manag. 2017, 148, 317-329. [CrossRef]

13. Aali, A.; Pourmahmoud, N.; Zare, V. Exergoeconomic analysis and multi-objective optimization of a novel combined flash-binary cycle for Sabalan geothermal power plant in Iran. Energy Convers. Manag. 2017, 143, 377-390. [CrossRef]

14. Boyaghchi, F.A.; Chavoshi, M. Multi-criteria optimization of a micro solar-geothermal CCHP system applying water/CuO nanofluid based on exergy, exergoeconomic and exergoenvironmental concepts. Appl. Therm. Eng. 2017, 112, 660-675. [CrossRef]

15. Shamoushaki, M.; Aliehyaei, M.; Ghanatir, F. Exergy, economic and environmental analysis and multi-objective optimization of a SOFC-GT power plant. Energy 2017, 134, 515-531. [CrossRef]

16. Ghaebi, H.; Parikhani, T.; Rostamzadeh, H.; Farhang, B. Proposal and assessment of a novel geothermal combined cooling and power cycle based on Kalina and ejector refrigeration cycles. Appl. Therm. Eng. 2018, 130, 767-781. [CrossRef]

17. Bianchi, M.; Branchini, L.; De Pascale, A.; Melino, F.; Ottaviano, S.; Peretto, A.; Torricelli, N.; Zampieri, G. Performance and operation of micro-ORC energy system using geothermal heat source. Energy Procedia 2018, 148, 384-391. [CrossRef]

18. Leveni, M.; Manfrida, G.; Cozzolino, R.; Mendecka, B. Energy and exergy analysis of cold and power production from the geothermal reservoir of Torre Alfina. Energy 2019, 180, 807-818. [CrossRef]

19. Ehyaei, M.; Ahmadi, A.; Assad, M.E.H.; Rosen, M.A. Investigation of an integrated system combining an organic Rankine cycle and absorption chiller driven by geothermal energy: Energy, exergy, and economic analyses and optimization. J. Clean. Prod. 2020, 258, 120780. [CrossRef]

20. Braimakis, K.; Magiri-Skouloudi, D.; Grimekis, D.; Karellas, S. Energy-exergy analysis of ultra-supercritical biomass-fuelled steam power plants for industrial CHP, district heating and cooling. Renew. Energy 2020, 154, 252-269. [CrossRef]

21. Wang, N.; Zhang, S.; Fei, Z.; Zhang, W.; Shao, L.; Sardari, F. Thermodynamic performance analysis a power and cooling generation system based on geothermal flash, organic Rankine cycles, and ejector refrigeration cycle; application of zeotropic mixtures. Sustain. Energy Technol. Assess. 2020, 40, 100749. [CrossRef]

22. Tian, M.-W.; Parikhani, T.; Jermsittiparsert, K.; Ashraf, M.A. Exergoeconomic optimization of a new double-flash geothermalbased combined cooling and power (CCP) system at two different cooling temperatures assisted by boosters. J. Clean. Prod. 2020, 261, 120921. [CrossRef]

23. Ahmadi, A.; Assad, M.E.H.; Jamali, D.H.; Kumar, R.; Li, Z.; Salameh, T.; Al-Shabi, M.; Ehyaei, M. Applications of geothermal organic Rankine Cycle for electricity production. J. Clean. Prod. 2020, 274, 122950. [CrossRef]

24. Assad, M.E.H.; Aryanfar, Y.; Radman, S.; Yousef, B.; Pakatchian, M. Energy and exergy analyses of single flash geothermal power plant at optimum separator temperature. Int. J. Low-Carbon Technol. 2021. [CrossRef]

25. Gholizadeh, T.; Vajdi, M.; Rostamzadeh, H. A new trigeneration system for power, cooling, and freshwater production driven by a flash-binary geothermal heat source. Renew. Energy 2020, 148, 31-43. [CrossRef]

26. Ding, P.; Zhang, K.; Yuan, Z.; Wang, Z.; Li, D.; Chen, T.; Shang, J.; Shofahaei, R. Multi-objective optimization and exergoeconomic analysis of geothermal-based electricity and cooling system using zeotropic mixtures as the working fluid. J. Clean. Prod. 2021, 294, 126237. [CrossRef] 
27. Cao, Y.; Mihardjo, L.W.; Dahari, M.; Ghaebi, H.; Parikhani, T.; Mohamed, A.M. An innovative double-flash binary cogeneration cooling and power (CCP) system: Thermodynamic evaluation and multi-objective optimization. Energy 2021, $214,118864$. [CrossRef]

28. NIST Standard Reference Database 23. NIST Thermodynamic and Transport Properties of Refrigerants and Refrigerant Mixtures REFPROP, 2013, Version 9.1. Available online: https:/ /www.nist.gov/publications/nist-standard-reference-database-23 -reference-fluid-thermodynamic-and-transport (accessed on 10 August 2020).

29. Bina, S.M.; Jalilinasrabady, S.; Fujii, H. Exergoeconomic analysis and optimization of single and double flash cycles for Sabalan geothermal power plant. Geothermics 2018, 72, 74-82. [CrossRef]

30. Zeinodini, M.; Aliehyaei, M. Energy, exergy, and economic analysis of a new triple-cycle power generation configuration and selection of the optimal working fluid. Mech. Ind. 2019, 20, 501. [CrossRef]

31. Wang, J.; Wang, J.; Dai, Y.; Zhao, P. Thermodynamic analysis and optimization of a flash-binary geothermal power generation system. Geothermics 2015, 55, 69-77. [CrossRef]

32. Li, H.; Bu, X.; Wang, L.; Long, Z.; Lian, Y. Hydrocarbon working fluids for a Rankine cycle powered vapor compression refrigeration system using low-grade thermal energy. Energy Build. 2013, 65, 167-172. [CrossRef]

33. Li, Z.; Ehyaei, M.; Kasmaei, H.K.; Ahmadi, A.; Costa, V. Thermodynamic modeling of a novel solar powered quad generation system to meet electrical and thermal loads of residential building and syngas production. Energy Convers. Manag. 2019, 199, 111982. [CrossRef]

34. Bejan, A.; Tsatsaronis, G.; Moran, M. Thermal Design and Optimization; John Wiley and Sons Inc.: New York, NY, USA, 1996.

35. Ghasemian, E.; Ehyaei, M.A. Evaluation and optimization of organic Rankine cycle (ORC) with algorithms NSGA-II, MOPSO, and MOEA for eight coolant fluids. Int. J. Energy Environ. Eng. 2017, 9, 39-57. [CrossRef]

36. Shamoushaki, M.; Ehyaei, M.A. Exergy, economic and environmental (3E) analysis of a gas turbine power plant and optimization by MOPSO algorithm. Therm. Sci. 2018, 22, 2641-2651. [CrossRef]

37. Shokati, N.; Ranjbar, F.; Yari, M. Comparative and parametric study of double flash and single flash/ORC combined cycles based on exergoeconomic criteria. Appl. Therm. Eng. 2015, 91, 479-495. [CrossRef]

38. Tjahjono, T.; Ehyaei, M.; Ahmadi, A.; Hoseinzadeh, S.; Memon, S. Thermo-economic analysis on integrated $\mathrm{CO}_{2}$, organic Rankine cycles, and $\mathrm{NaClO}$ plant using liquefied natural gas. Energies 2021, 14, 2849. [CrossRef]

39. Lazzaretto, A.; Tsatsaronis, G. SPECO: A systematic and general methodology for calculating efficiencies and costs in thermal systems. Energy 2006, 31, 1257-1289. [CrossRef]

40. Shamoushaki, M.; Ghanatir, F.; Ehyaei, M.; Ahmadi, A. Exergy and exergoeconomic analysis and multi-objective optimisation of gas turbine power plant by evolutionary algorithms. Case study: Aliabad Katoul power plant. Int. J. Exergy 2017, 22, 279. [CrossRef]

41. Talebizadehsardari, P.; Ehyaei, M.; Ahmadi, A.; Jamali, D.H.; Shirmohammadi, R.; Eyvazian, A.; Ghasemi, A.; Rosen, M.A. Energy, exergy, economic, exergoeconomic, and exergoenvironmental (5E) analyses of a triple cycle with carbon capture. J. $\mathrm{CO}_{2} \mathrm{Util}$. 2020, 41, 101258. [CrossRef]

42. Cui, P.; Yu, M.; Liu, Z.; Zhu, Z.; Yang, S. Energy, exergy, and economic (3E) analyses and multi-objective optimization of a cascade absorption refrigeration system for low-grade waste heat recovery. Energy Convers. Manag. 2019, 184, 249-261. [CrossRef]

43. Fiaschi, D.; Manfrida, G.; Rogai, E.; Talluri, L. Exergoeconomic analysis and comparison between ORC and Kalina cycles to exploit low and medium-high temperature heat from two different geothermal sites. Energy Convers. Manag. 2017, 154, 503-516. [CrossRef]

44. Parikhani, T.; Azariyan, H.; Behrad, R.; Ghaebi, H.; Jannatkhah, J. Thermodynamic and thermoeconomic analysis of a novel ammonia-water mixture combined cooling, heating, and power (CCHP) cycle. Renew. Energy 2020, 145, 1158-1175. [CrossRef]

45. Bina, S.M.; Jalilinasrabady, S.; Fujii, H. Thermo-economic evaluation of various bottoming ORCs for geothermal power plant, determination of optimum cycle for Sabalan power plant exhaust. Geothermics 2017, 70, 181-191. [CrossRef]

46. Turton, R.; Bailie, R.C.; Whiting, W.B.; Shaeiwitz, J.A. Analysis, Synthesis and Design of Chemical Processes, 2nd ed.; Prentice Hall: Upper Saddle River, NJ, USA, 2003.

47. Zoghi, M.; Habibi, H.; Chitsaz, A.; Javaherdeh, K.; Ayazpour, M. Exergoeconomic analysis of a novel trigeneration system based on organic quadrilateral cycle integrated with cascade absorption-compression system for waste heat recovery. Energy Convers. Manag. 2019, 198, 111818. [CrossRef]

48. Mosaffa, A.; Farshi, L.G.; Ferreira, C.I.; Rosen, M. Exergoeconomic and environmental analyses of CO2/NH3 cascade refrigeration systems equipped with different types of flash tank intercoolers. Energy Convers. Manag. 2016, 117, 442-453. [CrossRef]

49. Parikhani, T.; Ghaebi, H.; Rostamzadeh, H. A novel geothermal combined cooling and power cycle based on the absorption power cycle: Energy, exergy and exergoeconomic analysis. Energy 2018, 153, 265-277. [CrossRef]

50. Chemical Engineering, Economic Index. Available online: https://www.chemengonline.com/site/plant-cost-index/ (accessed on 18 October 2019).

51. Liu, X.; Yang, X.; Yu, M.; Zhang, W.; Wang, Y.; Cui, P.; Zhu, Z.; Ma, Y.; Gao, J. Energy, exergy, economic and environmental (4E) analysis of an integrated process combining $\mathrm{CO} 2$ capture and storage, an organic Rankine cycle and an absorption refrigeration cycle. Energy Convers. Manag. 2020, 210, 112738. [CrossRef]

52. Karellas, S.; Schuster, A.; Leontaritis, A.-D. Influence of supercritical ORC parameters on plate heat exchanger design. Appl. Therm. Eng. 2012, 33-34, 70-76. [CrossRef] 
53. Bergman, T.L.; Incropera, F.P.; DeWitt, D.P.; Lavine, A.S. Fundamentals of Heat and Mass Transfer; John Wiley \& Sons: Hoboken, NJ, USA, 2011.

54. Jackson, J.D.; Hall, W.B. Forced convection heat transfer. In Turbulent Forced Convection in Channels and Bundles: Theory and Applications to Heat Exchangers and Nuclear Reactors; Kakaç, S., Spalding, D.B., Eds.; Hemisphere Publishing Corporation: London, UK, 1979; p. 563.

55. Karimi, S.; Mansouri, S. A comparative profitability study of geothermal electricity production in developed and developing countries: Exergoeconomic analysis and optimization of different ORC configurations. Renew. Energy 2018, 115, 600-619. [CrossRef]

56. Kost, C.; Mayer, J.N.; Thomsen, J.; Hartmann, N.; Senkpiel, C.; Philipps, S.; Nold, S.; Lude, S.; Saad, N.; Schlegl, T. Levelized cost of electricity renewable energy technologies. Fraunhofer Inst. Sol. Energy Syst. ISE 2013, 144, 1-42.

57. Shengjun, Z.; Huaixin, W.; Tao, G. Performance comparison and parametric optimization of subcritical Organic Rankine Cycle $(O R C)$ and transcritical power cycle system for low-temperature geothermal power generation. Appl. Energy 2011, 88, 2740-2754. [CrossRef]

58. Tomasini-Montenegro, C.; Santoyo-Castelazo, E.; Gujba, H.; Romero, R.J.; Santoyo, E. Life cycle assessment of geothermal power generation technologies: An updated review. Appl. Therm. Eng. 2017, 114, 1119-1136. [CrossRef]

59. Ratlamwala, T.A.; Dincer, I.; Gadalla, M.A. Comparative environmental impact and sustainability assessments of hydrogen and cooling production systems. In Causes, Impacts and Solutions to Global Warming; Springer: Berlin/Heidelberg, Germany, 2013; pp. 389-408.

60. Hashemian, N.; Noorpoor, A. Assessment and multi-criteria optimization of a solar and biomass-based multi-generation system: Thermodynamic, exergoeconomic and exergoenvironmental aspects. Energy Convers. Manag. 2019, 195, 788-797. [CrossRef]

61. Kolahi, M.-R.; Nemati, A.; Yari, M. Performance optimization and improvement of a flash-binary geothermal power plant using zeotropic mixtures with PSO algorithm. Geothermics 2018, 74, 45-56. [CrossRef] 